\title{
Millennial-scale varnish microlamination dating of late Pleistocene geomorphic features in the drylands of western USA
}

\author{
Tanzhuo Liu *, Wallace S. Broecker \\ Lamont-Doherty Earth Observatory, Columbia University, Palisades, NY 10964, USA
}

\section{A R T I C L E I N F O}

\section{Article history:}

Received 10 September 2012

Received in revised form 20 December 2012

Accepted 21 December 2012

Available online 7 January 2013

\section{Keywords}

Rock varnish

VML dating

Climate change

Alluvial fan

Aggradation

Western USA

\begin{abstract}
A B S T R A C T
Varnish microlamination (VML) dating is a climate-based correlative age determination technique used to correlate and date various geomorphic features in deserts. In this study, we establish a generalized late Pleistocene (18-74 ka) millennial-scale microlamination sequence in fine-grained, fast-accumulating rock varnish for the drylands of western USA, radiometrically calibrate the sequence and correlate it with the $\delta^{18} \mathrm{O}$ record in the GISP2 Greenland ice core. We then use this climate-correlated varnish microstratigraphy to estimate surface exposure ages for radiometrically dated late Pleistocene geomorphic features in the study region. The VML dating of debris flow deposits on the Sehoo recessional shorelines of Lake Lahontan at the Jessup embayment of central Nevada yields a minimum-limiting age of $14.95-15.95 \mathrm{ka}$, in good agreement with a calibrated ${ }^{14} \mathrm{C}$ age of $15.22 \pm 0.12 \mathrm{ka}$ for the timing of the lake recession. The VML dating of a giant ejecta block on the rim of Meteor Crater in northern Arizona yields a minimum-limiting age of $49.15 \mathrm{ka}$, closely matching a thermoluminescence (TL) age of $49 \pm 3 \mathrm{ka}$ and slightly younger than a recently updated cosmogenic ${ }^{36} \mathrm{Cl}$ age of $56.0 \pm 2.4 \mathrm{ka}$ for the meteor impact event. The VML dating of distal Q2c fan surfaces on Hanaupah Canyon alluvial fan in Death Valley, California, yields a minimum-limiting age of $73.55 \mathrm{ka}$, in accord with cosmogenic ${ }^{36} \mathrm{Cl}$ depth-profile ages of $66+22 /-14 \mathrm{ka}$ and $72+24 /-20 \mathrm{ka}$ for the same fan deposits. The close agreement between the VML age estimates and the independently derived radiometric ages for these geomorphic features attests to the validity and reliability of millennial-scale VML dating.

To further assess its potential in desert geomorphological research, we use the VML method to study alluvial-fan responses to millennial-scale climatic changes. The VML dating of a small tributary fan in Death Valley reveals two episodes of fan aggradation, one ceasing at 73.55-86.75 ka during the dry period of the last interglacial (MIS 5a) and the other finishing at $66.15 \mathrm{ka}$ during the wet period of the last glacial (MIS 4). The VML and ${ }^{36} \mathrm{Cl}$ dating of the distal Q2c fan surfaces on Hanaupah Canyon fan reveal two episodes of large-scale fan aggradation ended at $72+24 /-20 \mathrm{ka}$ and $73.55 \mathrm{ka}$ during the wet period of MIS 4 . Fanhead incision and associated within-channel or fantoe aggradation are found to take place during the relatively dry period of the glacial-to-interglacial climatic transition (12-24 ka) and the Holocene interglacial dry period (0-12 ka). These data indicate that, on the millennial to sub-Milankovitch timescale $\left(\sim 10^{3}-\right.$ $10^{4}$ years), fan aggradation is a discrete sedimentational process under various climatic conditions. Because fan aggradation is ultimately controlled by the intensity and frequency of precipitation events - which in turn are modulated by major climatic oscillations such as Heinrich events, Dansgaard/Oeschger (DO) events, and glacial/interglacial shifts - these major climatic changes could be the pacemaker of regionally contemporaneous large-area fan segmentation.
\end{abstract}

(c) 2013 Elsevier B.V. All rights reserved.

\section{Introduction}

The effects of climatic change on desert alluvial fans have long been an important research topic as well as a challenging task in geomorphology for several reasons. First, alluvial fans are distinct and ubiquitous terrestrial landforms in deserts, and the geomorphic processes responsible for their formation and evolution may hold a key to our understanding of past environments, especially climatic

\footnotetext{
* Corresponding author. Tel.: +1 845365 8630; fax: +1 8453658777 .

E-mail address: tanzhuo@ldeo.columbia.edu (T. Liu).
}

changes in drylands (e.g., Bull, 1964; Lustig, 1965; Bull, 1977; Bull and Schick, 1979; Wells et al., 1987; Dorn, 1988; Frostick and Reid, 1989; Bull, 1991; Throckmorton and Reheis, 1993; Harvey et al., 1999; McDonald et al., 2003; Pope and Wilkinson, 2005; Reheis et al., 2005; Bacon et al., 2010; Miller et al., 2010; Enzel et al., 2012). Secondly, unlike paleolake shorelines and glacial moraines, whose existence is directly connected to climatic events, alluvial fans are formed in various climatic conditions with little difference in their depositional features (e.g., Brierley et al., 1993; Ibbeken et al., 1998; Krzyszkowski and Zielinkski, 2002; Ballantyne and Stone, 2004; Harvey et al., 2005; Lafortune et al., 2006). Accordingly, 
they cannot be utilized to generically infer climatic changes through sedimentological, stratigraphic or geomorphological analyses (Dorn, 2009a). Thirdly, accurate and precise dating of alluvial-fan deposits in a desert environment has been difficult. Accelerator mass spectrometry (AMS) radiocarbon dating of organic matter can certainly yield ages up to centennial resolution (Keefer et al., 2003), but alluvial fan deposits in drylands often lack such material because of its poor preservation in surficial oxidizing environments. Cosmogenic ${ }^{10} \mathrm{Be}$ and ${ }^{36} \mathrm{Cl}$ radionuclide methods have been increasingly used in surface exposure age determination on alluvial fans over the past two decades (e.g., Nishiizumi et al., 1993; Bierman et al., 1995; Repka et al., 1997; Zehfuss et al., 2001; van der Woerd et al., 2002; Phillips et al., 2003; Matmon et al., 2005; Vassallo et al., 2005; Evenstar et al., 2006; Kirby et al., 2006; van der Woerd et al., 2006; Frankel et al., 2007; Oskin et al., 2007; Machette et al., 2008; Behr et al., 2010; Owen et al., 2011). However, inherited prior exposure associated with alluvial deposits often leads to large dating uncertainties that, in most cases, do not permit unambiguous correlation of fan aggradation events with millennialscale climatic changes.

Varnish microlamination (VML) dating is a correlative age determination tool (cf. terminology in Colman et al., 1987). It is suitable for dating various desert landforms and archaeological features on which rock varnish has formed (Liu and Dorn, 1996; Bell et al.,
1998; Liu, 2003; Liu and Broecker, 2007, 2008a; Stirling et al., 2010). It is also capable of directly linking climatic changes with geomorphic events on the millennial timescale (Liu and Broecker, 2007, 2008b). In this paper, we first establish a generalized late Pleistocene (i.e., 18-74 ka) millennial-scale varnish layering sequence for the drylands of western USA (Fig. 1) and correlate it with the $\delta^{18} \mathrm{O}$ record in the GISP2 Greenland ice core (Alley et al., 1993; Grootes et al., 1993; Bender et al., 1994; Meese et al., 1994). We then employ this climatically correlated varnish layering sequence as a correlative dating tool to determine surface exposure ages of late Pleistocene geomorphic features in the study region. Results from these studies add new insights into our current understanding of how alluvial fans in the western USA drylands responded to millennial-scale climatic changes during the last glacial/interglacial cycle.

\section{VML dating}

Rock varnish is a slowly accreting (1-40 $\mu \mathrm{m} / \mathrm{ky}) \mathrm{Mn}$ - and Fe-rich dark coating on subaerially exposed rock surfaces in drylands (Potter and Rossman, 1977; Dorn and Oberlander, 1981; Liu and Broecker, 2000) (Fig. 2A). Because of its sedimentary origin, varnish often contains a layered microstratigraphy that records past climatic changes (Perry and Adams, 1978; Dorn, 1988; Liu and Dorn, 1996; Liu et al.,

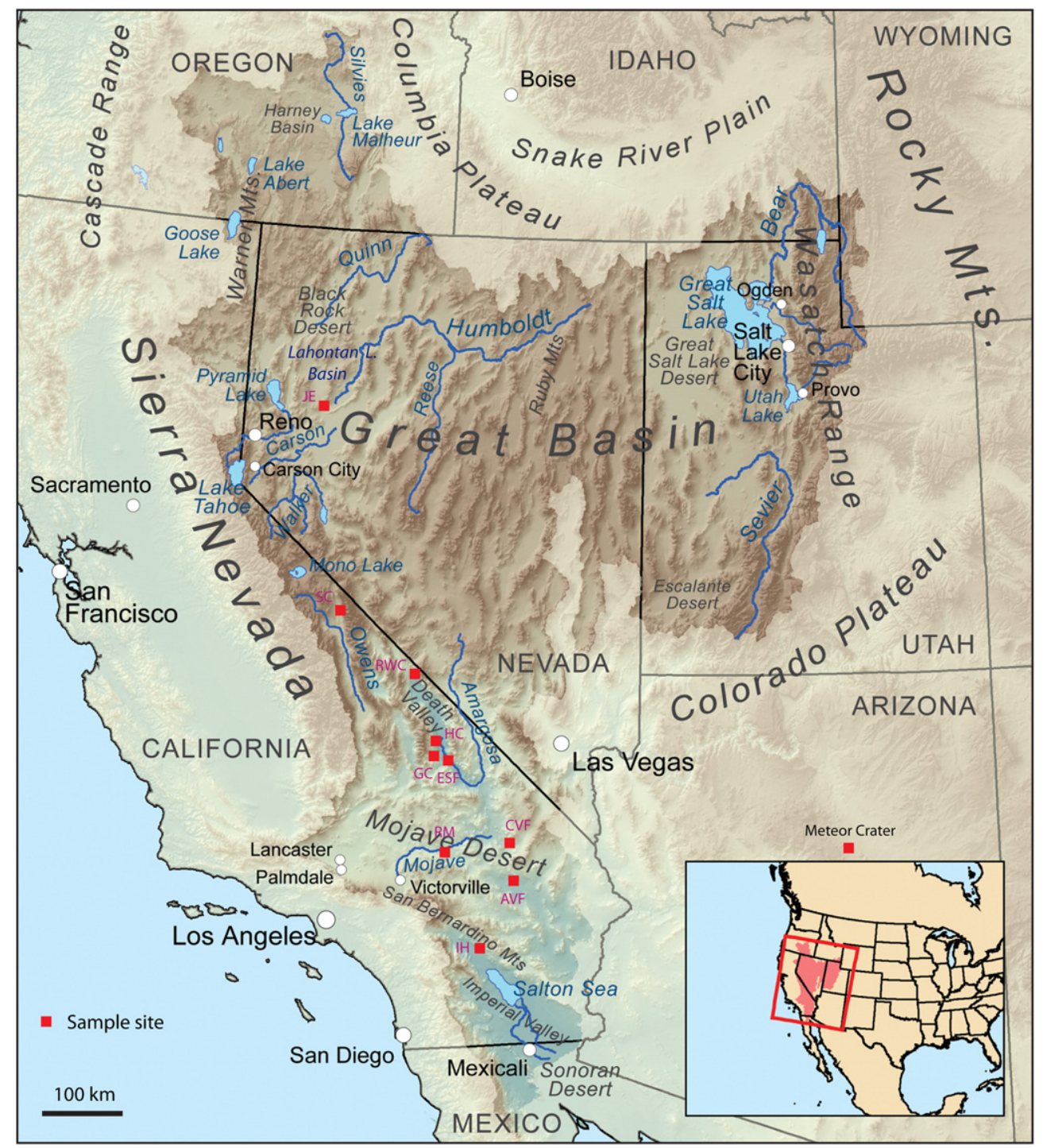

Fig. 1. Map showing sample sites and key landmarks in the dryland regions of the Great Basin in western USA (base map courtesy of upload.Wikimedia.org). 

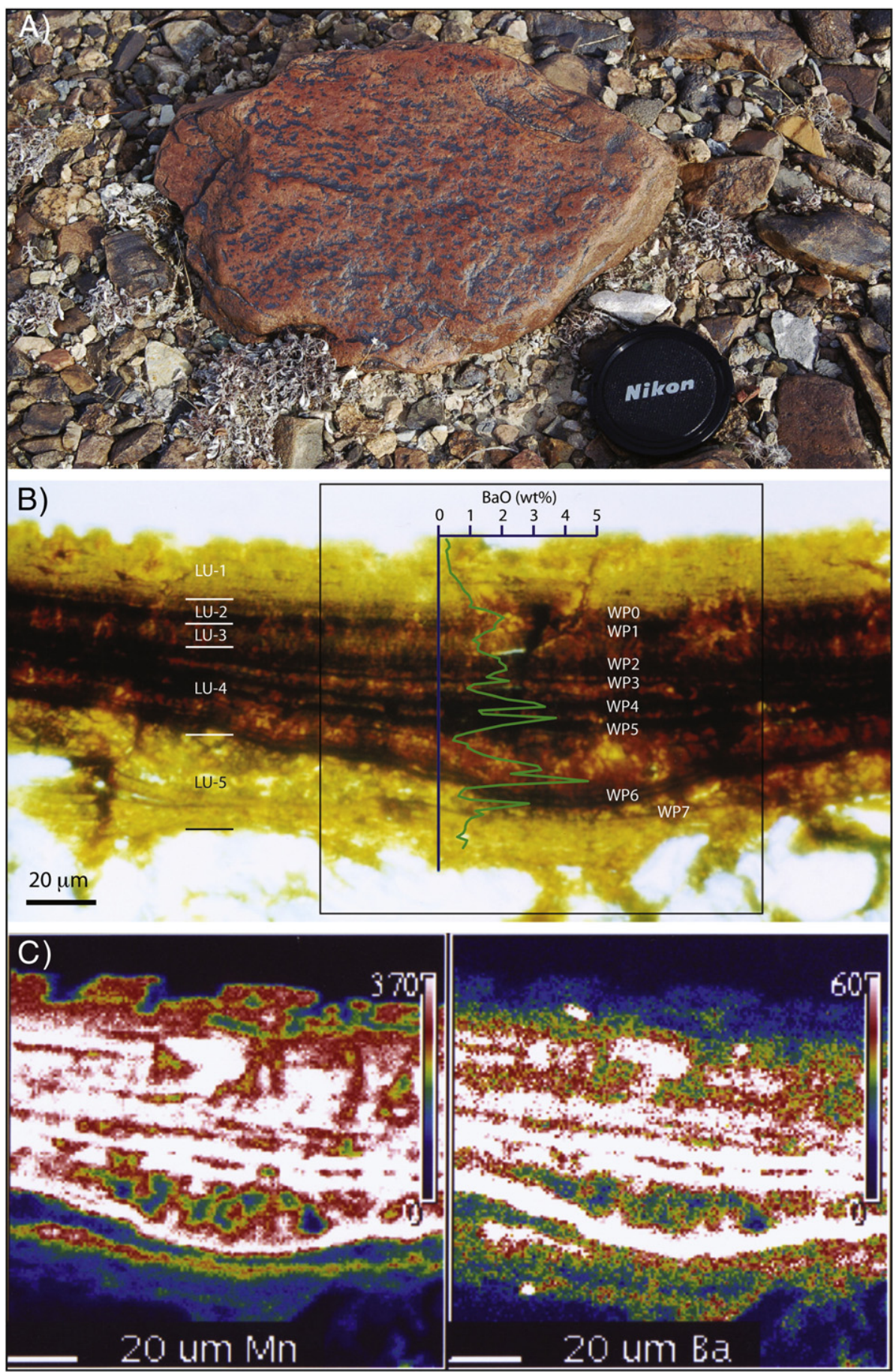

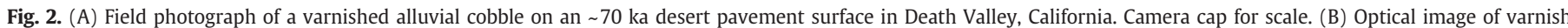

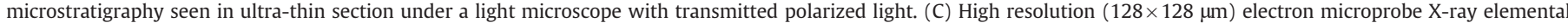

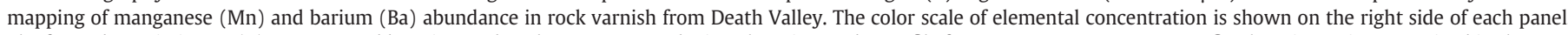

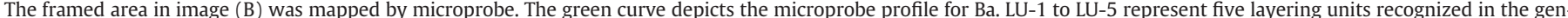

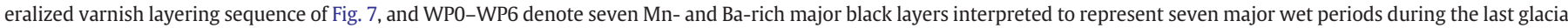

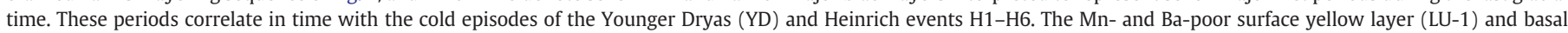

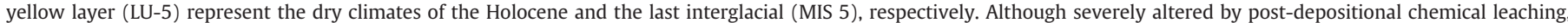
black layer WP7 represents an earlier wet period in the varnish record, likely coeval with the cold reversal of MIS 5b during the last interglacial.

2000; Broecker and Liu, 2001; Liu and Broecker, 2008a,b) (Fig. 2B). In the Great Basin of western USA, Mn- and Ba-poor varnish layers contain $<15 \% \mathrm{MnO}$ and $<0.5 \% \mathrm{BaO}$. In ultra-thin sections (5-10 $\mu \mathrm{m}$ thick) under transmitted polarized light, they are yellow (Figs. 2B, C and $6 \mathrm{~A})$. These layers were formed during the dry Holocene. The Mn- and Ba-rich black layers contain $25-45 \% \mathrm{MnO}$ and $1-4 \% \mathrm{BaO}$ (Figs. 2B, C and 6A). They were deposited during the last glacial time when the Great Basin was much wetter than at present (Broecker and Liu, 2001). The orange layers in varnish microstratigraphy contain 1525\% $\mathrm{MnO}$ and $0.5-1 \% \mathrm{BaO}$ (Figs. 2B, C and 6A). They were deposited when the climate was intermediate between maximum wet and maximum dry periods. Previous studies (Liu and Dorn, 1996; Liu 
et al., 2000) showed that wet events represented by the black layers in the western USA varnish correlate in time with cold episodes of the Younger Dryas (YD) and Heinrich events H1-H6 in the North Atlantic region (Fig. 3).

Varnish microlamination (VML) dating was first used as a correlative age-determination technique by Dorn (1988) to study the chronostratigraphy of alluvial-fan deposits on Hanaupah Canyon fan in Death Valley. Subsequent research (Liu, 1994; Liu and Dorn, 1996) developed VML as a geomorphic age determination tool in the Great Basin. The VML has now been used at various sites globally (Diaz et al., 2002; Lee and Bland, 2003; Dietzel et al., 2008; Zerboni, 2008; Dorn, 2010; Baied and Somonte, in press). The basic premise of this dating approach is that the formation of varnish microstratigraphy is mainly affected by regional and global climatic variations. Because climatic signals recorded in varnish are regionally and, in some cases, globally contemporaneous (Liu and Dorn, 1996; Liu et al., 2000), VML can be used as a correlative dating tool to provide minimum-limiting surface exposure ages for varnished geomorphic surfaces in the world's deserts. A rigorous blind test of this method was conducted on late Pleistocene lava flows in the Mojave Desert, California (Liu, 2003; Phillips, 2003). The nearly identical convergence between cosmogenic ${ }^{36} \mathrm{Cl}$ ages and VML age estimates for three basalt flows in the Pisgah, Cima, and Amboy volcanic fields demonstrates that VML is a valid age determination tool for late Pleistocene (12-85 ka) surficial geomorphic features in the drylands of western USA (Marston, 2003).

Additional studies in the Great Basin (Liu and Broecker, 2007) showed that, when fine-grained $(<1 \mu \mathrm{m})$ varnish accumulates rapidly enough, varnish microstratigraphy also records Holocene millennial-scale wet events that largely correlate in time with Holocene millennial-scale cooling events uncovered in North Atlantic deep sea sediments (Bond et al., 1997, 1999) (Fig. 4). This radiometrically calibrated and climatically correlated Holocene varnish microstratigraphy extended the VML dating potential to surficial geomorphic and geoarchaeological features of the Holocene (0-12 ka) (Liu and Broecker, 2007). Recent work (Liu and Broecker, 2008a,b) has further extended millennial-scale VML dating to late glacial time (12-18 ka) (Fig. 5) and dating potential to the late Quaternary $(85-300 \mathrm{ka})$.

\section{Late Pleistocene millennial-scale varnish microstratigraphy}

Returning to the time period of concern in this paper, $18-74 \mathrm{ka}$, we collected varnish samples from radiometrically dated and undated rocks in the dryland regions of western USA (Table 1; Fig. 1) and analyzed them to see whether the millennial-scale varnish microlaminae were regionally replicable (Fig. 6). Ultra-thin sections (5-10 $\mu \mathrm{m}$ thick) of varnish samples were prepared using an innovative thin sectioning technique (Liu and Dorn, 1996), which reduces failure rates from $80 \%$ to $<5 \%$ and permits rapid preparation and thus intercomparison of many sections. Conventional thin sections cannot be employed because they are too thick $(25-30 \mu \mathrm{m})$ and thus do not reveal the microstratigraphy. Ultra-thin sections were then photographed under a Leica DMLB polarized light microscope to yield high resolution $(\sim 1 \mu \mathrm{m})$ color images of varnish microstratigraphy for analysis of the layering pattern (Fig. 6). As in any stratigraphic analysis, unconformities occur in some sections and not in others. Thus, ultra-thin sections containing the most complete varnish microstratigraphy were selected for further chemical analyses

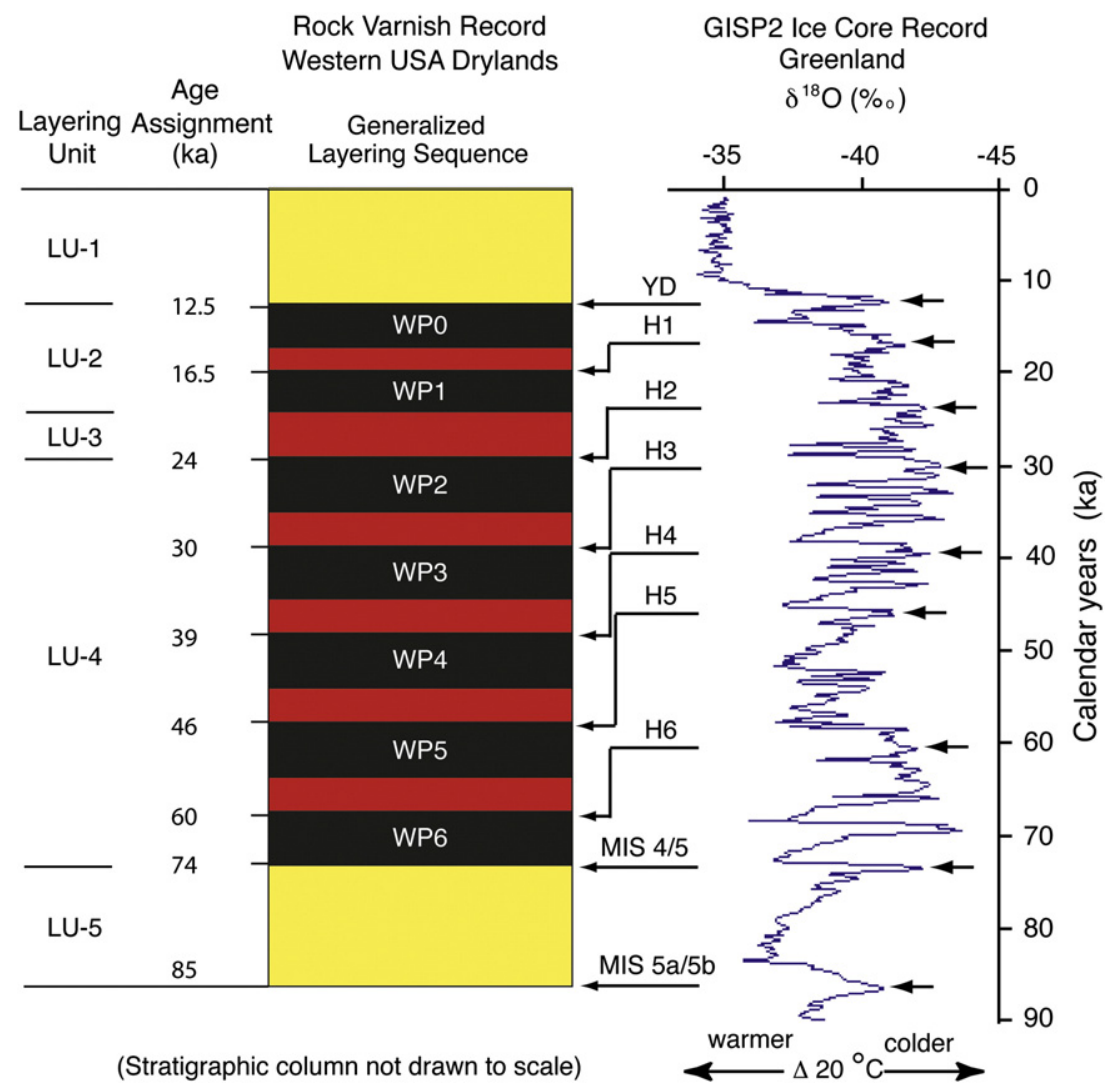

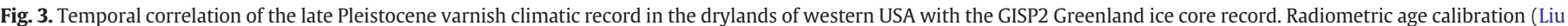

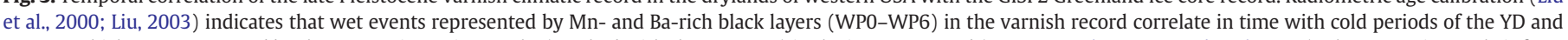

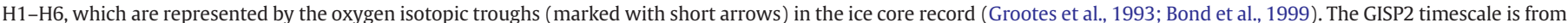

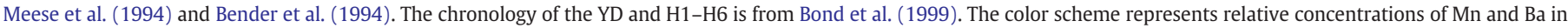

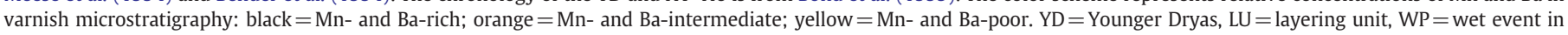
Pleistocene, MIS = Marine Isotope Stage. 


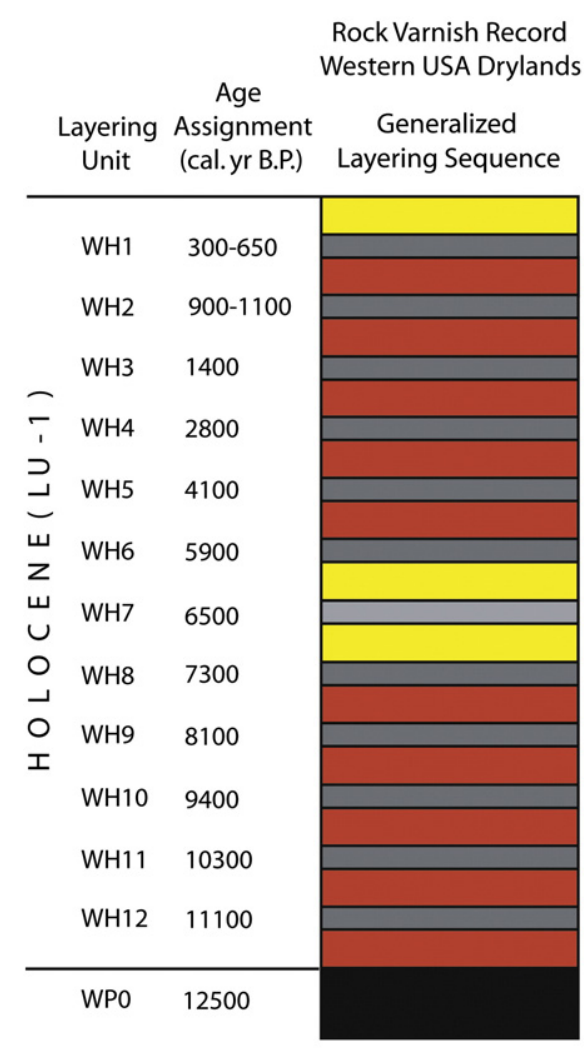

(Stratigraphic column not drawn to scale)

\section{Deep Sea Sediment Record \\ Subpolar North Atlantic}

(EW93-GGC36; Bond et al., 1999)

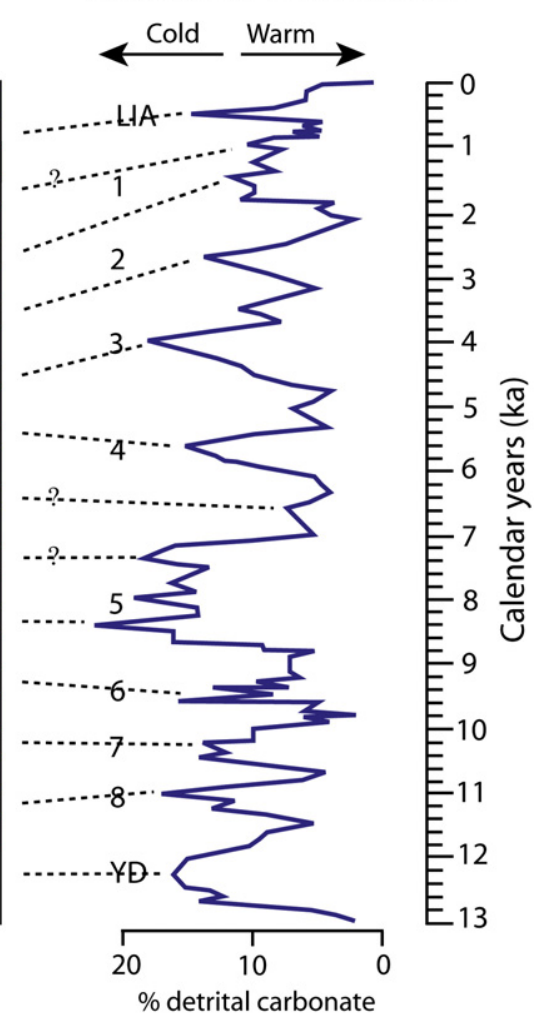

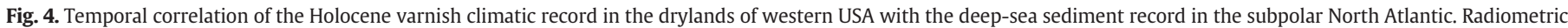

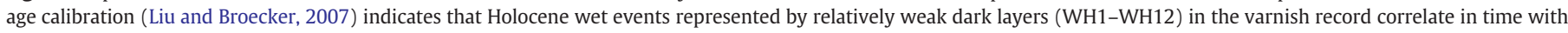

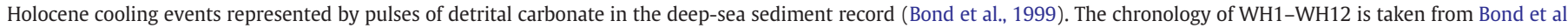

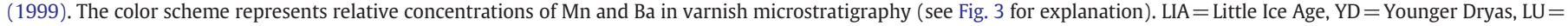
layering unit, $\mathrm{WH}=$ wet event in Holocene, $\mathrm{WP}=$ wet event in Pleistocene.

with a fully automated five-spectrometer CAMECA SX100 electron probe. Probe X-ray mapping and line profiling provide high resolution $(\sim 2 \mu \mathrm{m})$ chemical varnish microstratigraphy (Fig. 2C). A combination of both optical and chemical microstratigraphy allows detailed detection of Mn, Ba, and other elemental fluctuations in varnish.

Based on microstratigraphic sequences obtained from 582 ultra-thin sections of 315 varnish samples from 53 different sites scattered across the dryland regions of western USA, we created a composite master stratigraphy of yellow, orange, and black microlaminae (Fig. 7). Going backward in time, the youngest layer is yellow and is low in $\mathrm{Mn}$ and $\mathrm{Ba}$. We call it varnish layering unit 1 (LU-1); LU-1 represents the Holocene. Beneath LU-1 is LU-2, consisting of a pair of black layers (WP0 and WP1; where WP stands for "wet period in the Pleistocene") separated by a thin orange layer. Black layers WP0 and WP1 are subdivided into three and four minor black layers, respectively; and the orange layer lying between them contains two relatively weak minor black layers (Fig. 7). Next in the stratigraphic sequence is a relatively thick orange layer (LU-3). Beneath LU-3 is a sequence of five Mn- and Ba-rich major black layers (WP2-WP6) intercalated with four relatively thin orange layers. Each of these five black layers can be further subdivided into three or five minor black layers, when the rate of varnish accumulation is rapid enough to record such minor events. Combined, these black and orange layers form varnish layering unit 4 (LU-4). Together LU-2, LU-3, and LU-4 represent the last glacial. These units are underlain by a relatively thick $\mathrm{Mn}$ - and Ba-poor yellow layer intercalated with one black layer. These three layers constitute the late part of LU-5, which represents the last interglacial. Detailed descriptions of the characteristics of these millennial-scale varnish microlaminations are given in Table 2 and elsewhere (Liu and Dorn, 1996; Liu and Broecker, 2007, 2008b).

\section{Calibration of the late Pleistocene varnish microstratigraphy}

Radiometric age dating of varnish microlaminations is the most challenging task in establishing an absolute timescale for VML dating. Although dating the internal layers found within rock varnish directly would be ideal, no way has been found to do this. Instead we have examined varnish samples from sites on landforms that have been dated (Table 1; Figs. 8 and 9). In this way we establish maximum ages for the start of varnish accumulation.

New radiometric and OSL age constraints from this study (Table 1; Figs. 8 and 9) support our previous interpretation that varnish microstratigraphy records past wetness variations (Liu et al., 2000; Broecker and Liu, 2001). Wet periods represented by the black layers are correlated with the cold periods of the YD and Heinrich events H1H6 (Liu and Dorn, 1996; Liu, 2003) (Fig. 3). These age constraints further suggest that short-lived wet events represented by minor black layers in rapidly formed varnish microstratigraphy are associated with millennialscale cold phases in the Greenland ice core record (Table 1; Figs. 7-9). For example, varnish from an OSL-dated alluvial fan surface $(25.5 \pm 3.9 \mathrm{ka})$ in Death Valley (Sohn et al., 2007) displays a basal black layer WP2c (Fig. 8B), representing a short-lived wet event that is contemporaneous with the cooling phase at 25.55 ka seen in the Greenland ice core record. Varnish from a cosmogenic ${ }^{36} \mathrm{Cl}$-dated lava flow (46 $\pm 2 \mathrm{ka}$ ) in the Mojave Desert (Phillips, 2003) displays a basal black layer WP5b 


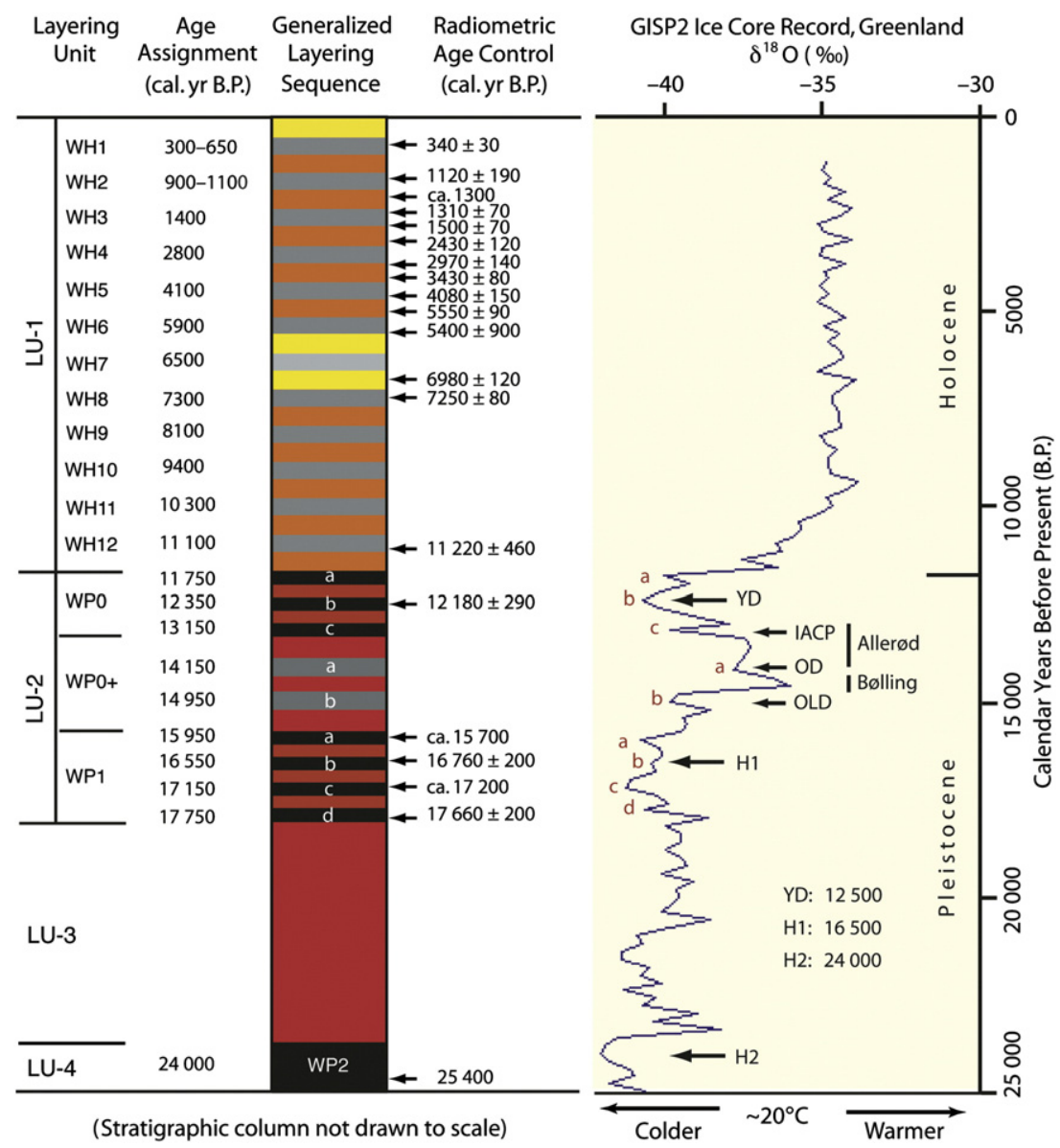

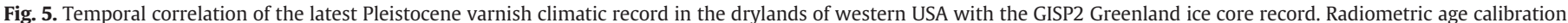

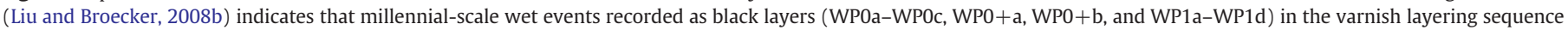

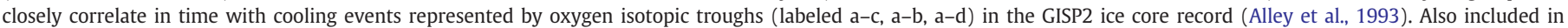

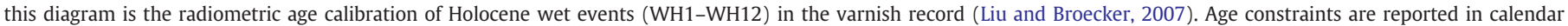

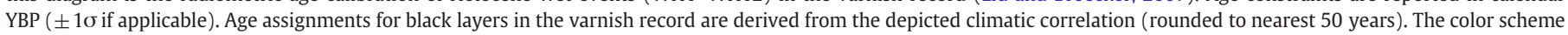

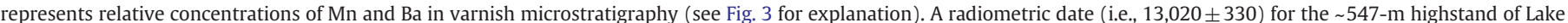

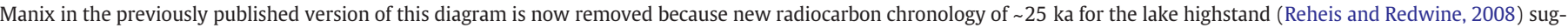

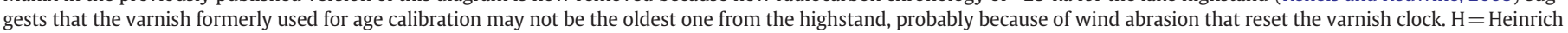

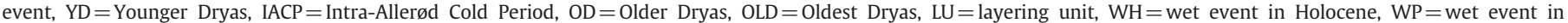
Pleistocene.

(Fig. 8E), representing a short-lived wet event that is coeval with the ice core cooling phase at $47.35 \mathrm{ka}$. Varnish from a cosmogenic ${ }^{10} \mathrm{Be}$-dated alluvial fan surface $(70+22 /-20 \mathrm{ka})$ in northern Death Valley (Frankel et al., 2007) displays a basal black layer WP6d (Fig. 8G), representing a short-lived wet event that is correlated with the cooling phase at $68.95 \mathrm{ka}$ in the ice core record.

These age constraints also suggest that short-lived dry events represented by minor orange layers in varnish microstratigraphy are associated with millennial-scale warm phases in the ice core record (Table 1; Figs. 7-9). For instance, varnish samples, one from a ${ }^{36} \mathrm{Cl}$-dated debris flow fan (22.5 $\pm 1.5 \mathrm{ka}$ ) in Owens Valley (Kirby et al., 2006) and the other from a ${ }^{14} \mathrm{C}$-dated alluvial fan surface $(28.1 \pm 0.6 \mathrm{ka}$; on a piece of charcoal) in Death Valley (Hooke and Dorn, 1992), display basal orange layers LU-3 and WP2c+ (Fig. 8A, C), respectively, representing two short-lived dry events synchronous with the warm phases of Dansgaard-Oeschger (DO) events 2 (23.3 ka) and 3 (27.74 ka) in the ice core record. Two more varnish samples - one from a ${ }^{10} \mathrm{Be}$-dated offset fan $(35.5 \pm 2.5 \mathrm{ka})$ along the San Andreas fault near the Indio Hills of southern California (van der Woerd et al., 2006) and the other from a ${ }^{10} \mathrm{Be}$-dated offset fan $(56.4 \pm 7.7 \mathrm{ka})$ along the Calico fault near Rodman Mountains in the Mojave Desert (Oskin et al.,
2007) - contain basal orange layers WP3d+ and WP5e+ (Fig. 8D, F), respectively, representing two short-lived dry events synchronous with the warm phases of DO events 7 (35.15 ka) and 16 (56.24 ka) in the ice core record.

The most striking feature of our varnish record is the extremely dry period represented by the Mn- and Ba-poor yellow layer of LU-5, which is both optically and chemically similar to the surface yellow layer of LU-1 diagnostic of the Holocene dry climate (Figs. 2B, 6F, 8H). The prominence of LU-5 and its similarity to LU- 1 strongly suggests that it represents the last interglacial dry climate. This interpretation is consistent with the stratigraphic position of the yellow layer in the generalized layering sequence, where it predates the last glacial black layers of LU-4. This interpretation is also substantiated by a cosmogenic ${ }^{36} \mathrm{Cl}$ age constraint of $79 \pm 5$ ka for this yellow layer (Phillips, 2003), suggesting that it was deposited just before the end $(\sim 74 \mathrm{ka})$ of the last interglacial (MIS 5) (Liu and Broecker, 2008a).

\section{Climatic implications}

A possible correlation may exist between cycles of wetness in the varnish record and Bond cycles (sawtooth-shaped cooling) (Bond 
Table 1

Rock varnish sample locations, geomorphic context, and age constraints ${ }^{\mathrm{a}}$

\begin{tabular}{|c|c|c|c|c|}
\hline & Sample site and geomorphic context & Latitude $(\mathrm{N})$ /longitude $(\mathrm{W})$ & Age constraint ${ }^{\mathrm{b}}(\mathrm{ka})$ & Age type and source \\
\hline \multicolumn{5}{|c|}{ Fig. 6} \\
\hline A & Anvil Canyon Fan, DV & $35^{\circ} 58^{\prime} 21.10^{\prime \prime} / 116^{\circ} 46^{\prime} 4.30^{\prime \prime}$ & Latest Pleistocene & Geomorphic age (this study) \\
\hline B & Hanaupah Canyon Fan, DV & $36^{\circ} 12^{\prime} 47.00^{\prime \prime} / 116^{\circ} 57^{\prime} 8.73^{\prime \prime}$ & Late Pleistocene & Geomorphic age (this study) \\
\hline $\mathrm{C}$ & Galena Canyon Fan, DV & $36^{\circ} 01^{\prime} 26.00^{\prime \prime} / 116^{\circ} 54^{\prime} 0.04^{\prime \prime}$ & " & " \\
\hline $\mathrm{D}$ & Cima Undated Lava Flow, MD & $35^{\circ} 11^{\prime} 41.59^{\prime \prime} / 115^{\circ} 49^{\prime} 39.00^{\prime \prime}$ & $"$ & $"$ \\
\hline E & Cima Undated Lava Flow, MD & $35^{\circ} 11^{\prime} 41.59^{\prime \prime} / 115^{\circ} 49^{\prime} 39.00^{\prime \prime}$ & $"$ & $"$ \\
\hline $\mathrm{F}$ & Galena Canyon Fan, DV & $36^{\circ} 01^{\prime} 47.00^{\prime \prime} / 116^{\circ} 52^{\prime} 51.00^{\prime \prime}$ & $"$ & $"$ \\
\hline \multicolumn{5}{|c|}{ Figs. 7-9 } \\
\hline A & Sabies Canyon Fan, OV & $37^{\circ} 34^{\prime} 45.46^{\prime \prime} / 118^{\circ} 21^{\prime} 1.28^{\prime \prime}$ & $22.5 \pm 1.5$ & ${ }^{36} \mathrm{Cl}$ (Kirby et al., 2006) \\
\hline $\mathrm{B}$ & Unnamed East-side Fan, DV & $35^{\circ} 58^{\prime} 11.88^{\prime \prime} / 116^{\circ} 42^{\prime} 55.82^{\prime \prime}$ & $25.5 \pm 3.9^{c}$ & OSL (Sohn et al., 2007) \\
\hline $\mathrm{C}$ & Hanaupah Canyon Fan, DV & $36^{\circ} 13^{\prime} 10.55^{\prime \prime} / 116^{\circ} 54^{\prime} 34.06^{\prime \prime}$ & $28.1 \pm 0.6^{\mathrm{d}}$ & ${ }^{14} \mathrm{C}$ (Hooke and Dorn, 1992) \\
\hline $\mathrm{D}$ & Biskra Palms Fan, IH & $33^{\circ} 47^{\prime} 2.23^{\prime \prime} / 116^{\circ} 14^{\prime} 49.04^{\prime \prime}$ & $35.5 \pm 2.5^{\mathrm{e}}$ & ${ }^{10} \mathrm{Be}$ (van der Woerd et al., 2006) \\
\hline E & Cima Lava Flow, MD & $35^{\circ} 11^{\prime} 42.00^{\prime \prime} / 115^{\circ} 49^{\prime} 39.00^{\prime \prime}$ & $46 \pm \overline{2}$ & ${ }^{36} \mathrm{Cl}$ (Phillips, 2003) \\
\hline $\mathrm{F}$ & Sheep Springs Wash Fan, RM & $34^{\circ} 44^{\prime} 49.28^{\prime \prime} / 116^{\circ} 36^{\prime} 11.92^{\prime \prime}$ & $56.4 \pm 7.7^{\mathrm{f}}$ & ${ }^{10} \mathrm{Be}$ (Oskin et al., 2007) \\
\hline G & Red Wall Canyon Fan, NDV & $36^{\circ} 52^{\prime} 38.18^{\prime \prime} / 117^{\circ} 15^{\prime} 35.02^{\prime \prime}$ & $70+22 /-20^{g}$ & ${ }^{10} \mathrm{Be}$ (Frankel et al., 2007) \\
\hline $\mathrm{H}$ & Amboy Lava Flow, MD & $34^{\circ} 32^{\prime} 49.00^{\prime \prime} / 115^{\circ} 47^{\prime} 47.00^{\prime \prime}$ & $79 \pm 5$ & ${ }^{36} \mathrm{Cl}$ (Phillips, 2003) \\
\hline
\end{tabular}

DV - Death Valley; IH - Indio Hills; MD - Mojave Desert; NDV - Northern Death Valley; OV - Owens Valley; RM - Rodman Mountains.

a All samples were collected from the arid regions of California, western USA. Ages are reported in calendar YBP (ka), with $\pm 1 \sigma$ error if applicable.

b In the drylands of western USA, the lag time between the abandonment of dated landforms and the onset of varnish formation is on the order of $\sim 10^{2}$ years (Liu and Broecker,

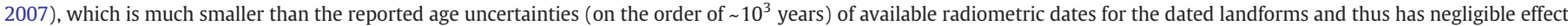
on age calibration of varnish basal layers.

c Calculated mean age of two originally reported OSL dates on quartz from fine-grained sand (24.7 \pm 3.6 and $26.2 \pm 4.12 \mathrm{ka})$.

d Calibrated age of a conventional radiocarbon date on charcoal ( $23.42 \pm 0.55$ ka; Beta 28805) using the calibration program of Fairbanks0107 calibration curve at http:// www.radiocarbon.ldeo.columbia.edu/research/radcarbcal.htm (Fairbanks et al., 2005).

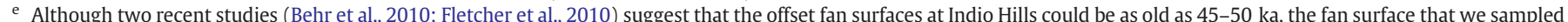

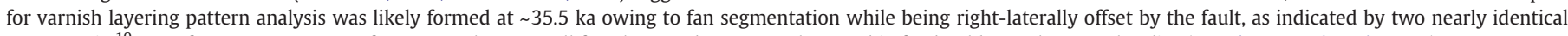
cosmogenic ${ }^{10} \mathrm{Be}$ surface exposure ages of $35.5 \pm 2.5 \mathrm{ka}$ on small fan clasts and $35.2 \pm 1.2 \mathrm{ka}$ on a big fan boulder at the same locality (van der Woerd et al., 2006 ).

$\mathrm{f}$ This age was reported with $\pm 2 \sigma$ error.

$\mathrm{g}$ This age was reported as a ${ }^{10} \mathrm{Be}$ model age of 70 ka based on probability density functions of 16 dates from surface clasts ranging from 50 to 92 ka.

et al., 1993) in the ice core record (Fig. 7). Short-lived wet periods, indicated by the minor black layers within WP0-WP6 (Fig. 7; Liu and Broecker, 2008b), appear to be largely associated with the cooling phases in each Bond cycle; short-lived dry periods are tied to the warm phases (Dansgaard et al., 1993). This suggests that wetness variations in the drylands of western USA were largely paced by millennial-scale climatic fluctuations in the North Atlantic, with regimes of wet (in the desert) and cold (in the arctic) alternating with dry (desert) and warm (arctic) between the two geographical regions during the last glacial time (Fig. 10B; Gray et al., 2003). This also agrees well with the marine sediment record of DO cycles of the past 25-60 ka from the Santa Barbara basin off the California coast (Behl and Kennett, 1996; Hendy and Kennett, 1999), suggesting that the northeast Pacific was, in fact, impacted by DO oscillations in the North Atlantic during the last glaciation.

Numerous studies have shown that the glacial wet/cold climatic regime in the present-day drylands of western USA may reflect the influence of mid-latitude westerly winds or the polar jet stream (PJS) in the northern hemisphere (e.g., COHMAP Members, 1988; Benson et al., 1995; Clark and Bartlein, 1995; Bartlein et al., 1998; Polyak et al., 2004). Earlier climate modeling (COHMAP Members, 1988; Bartlein et al., 1998) showed a southward displacement of the PJS by the Laurentide Ice Sheet during the last glacial maximum. Such a shift might be responsible for the highstands of pluvial Lake Lahontan during $\mathrm{H} 1$ and the prolonged wet period during the YD in the western USA (Benson et al., 1995; Polyak et al., 2004). Lake sediments in Germany indicate a substantial intensification and reorganization of mid-latitude westerlies during the YD (Brauer et al., 2008). Results from a coupled ocean-atmosphere general circulation model (Mikolajewicz et al., 1997) further suggest that the temporary shutdown of North Atlantic Deep Water (NADW) formation and associated surface cooling over the North Atlantic likely led to changes of sufficient magnitude in the northern hemisphere westerly wind belt that they could have affected sea surface temperature distribution and thus coastal upwelling and thermocline ventilation in the northeast Pacific related to the DO events. Studies of deep sea sediment cores from the Southern Ocean (Anderson et al., 2009) also suggest a concurrent southward shift of the Intertropical Convergence Zone (ITCZ) and southern hemisphere westerly wind belt during the YD and $\mathrm{H} 1$ (Fig. 10A) in response to sea ice formation resulting from a shutdown of NADW formation in the North Atlantic (Broecker and Denton, 1989).

Asmerom et al. (2010) presented a $\delta^{18} \mathrm{O}$-based precipitation record from a speleothem from New Mexico showing that episodes of increased winter precipitation of the last glacial time (11-56 ka) in the southwestern USA were associated with northern hemisphere YD and H1-H5 cooling events. They attributed this to southward shifts in the PJS that modulated the position of the winter storm track over North America (Fig. 10B). Were this the case for each millennial-scale cooling episode of the last glaciation, cold fronts driven by such intensified westerly winds when crossing over the northeast Pacific might cause stronger cyclonic activity, resulting in enhanced precipitation along the storm tracks in the coastal and inland regions of western USA (Enzel et al., 1989; Nakamura et al., 2008). This provides an important clue to the atmospheric mechanism by which the cooling of Greenland and the North Atlantic might be imprinted on varnishes accreting in the drylands of western North America.

\section{Tests of the calibrated late Pleistocene varnish microstratigraphy}

Once radiometrically calibrated and climatically correlated, varnish microstratigraphy can be used as a correlative dating tool to estimate numerical ages of geomorphic features in deserts (Liu and Dorn, 1996; Bell et al., 1998; Friend et al., 2000; Liu, 2003; Cerveny et al., 2006; Liu and Broecker, 2007; Dorn, 2009b; Stirling et al., 2010). In the following sections, we present four case studies to assess the potential use of the millennial-scale VML dating in studying a debris flow deposit on an abandoned shoreline, a meteor impact event, and aggradation events on two alluvial fans. To assign ages, we employ the VML age scale in Fig. 7, with the recognition that any varnish-based age estimates should be interpreted as minimum-limiting surface exposure ages for the dated geomorphic feature because some time must elapse before 

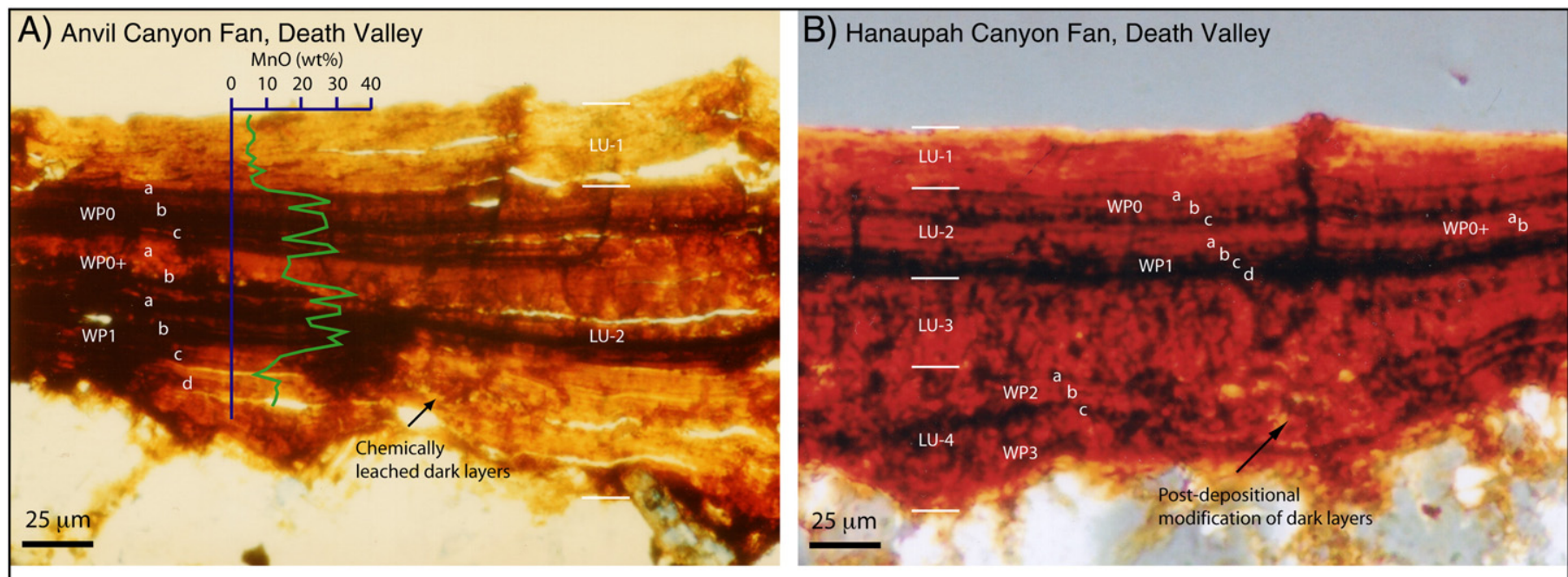

\section{C) Galena Canyon Fan, Death Valley}

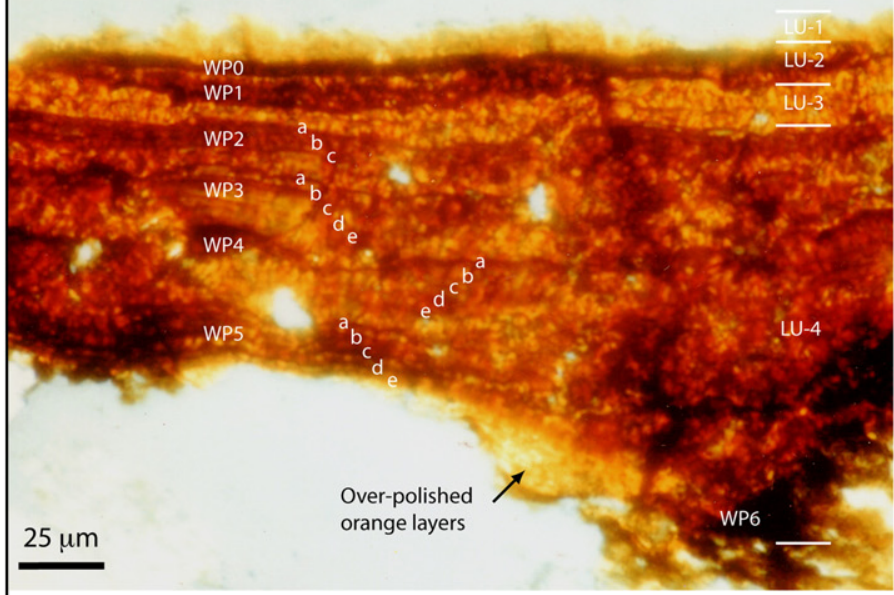

D) Undated Lava Flow, Cima Volcanic Field

\section{E) Undated Lava Flow, Cima Volcanic Field}

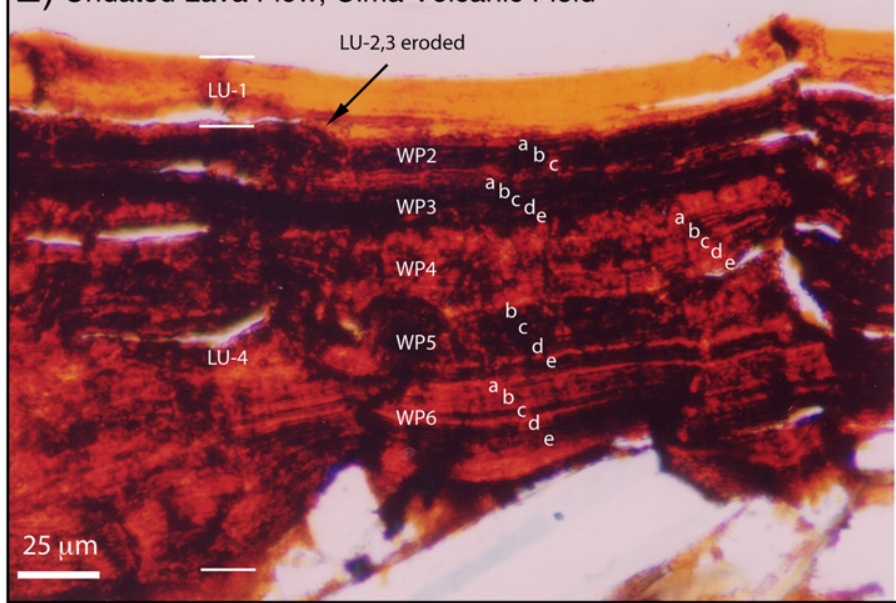

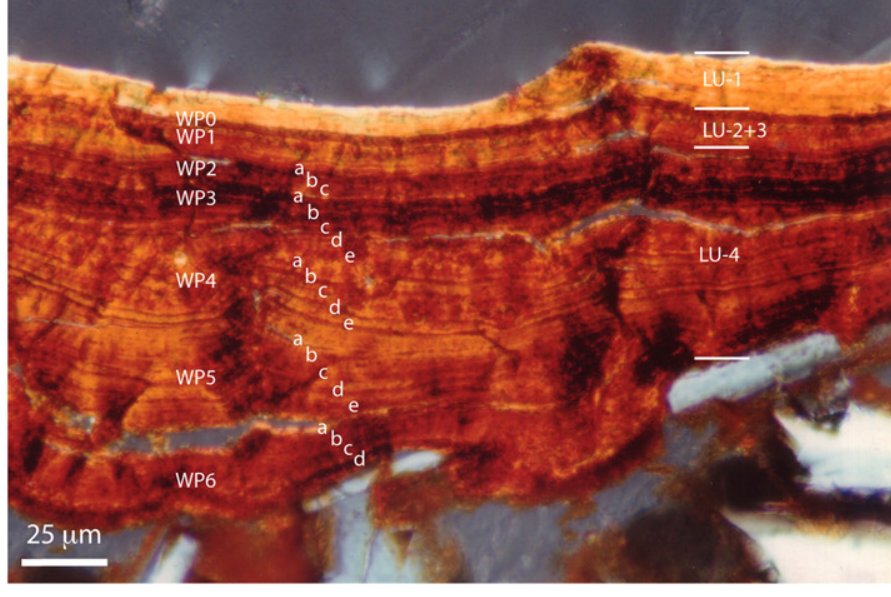

F) Galena Canyon Fan, Death Valley

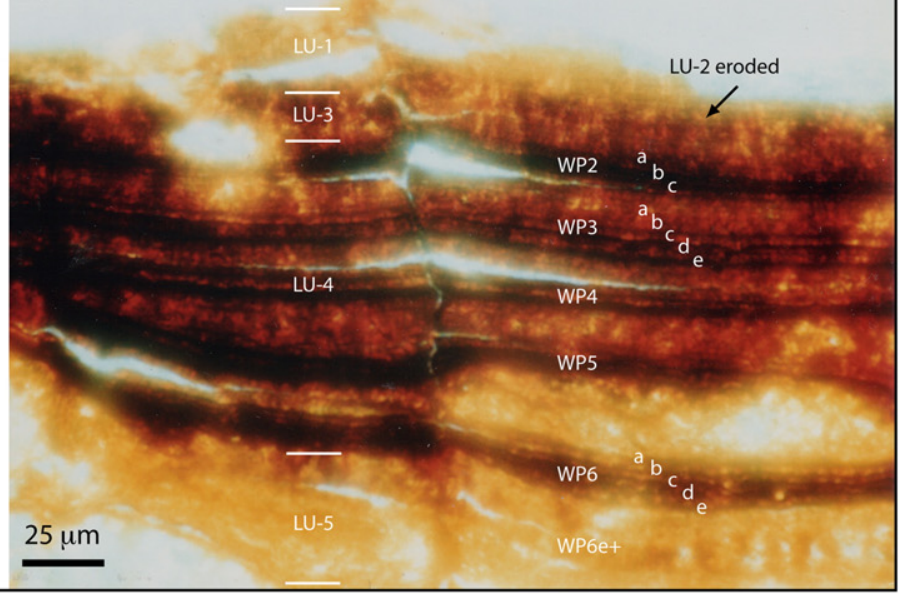

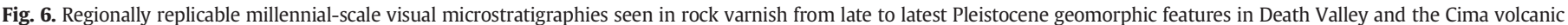

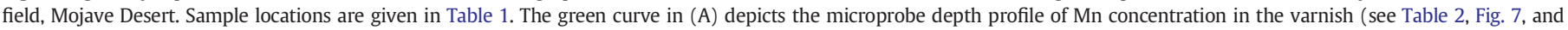
text for terminology and layering pattern interpretation).

varnish begins to form on a rock and that the ages are only as good as our radiometric calibration and climatic correlation.

\subsection{Debris flow on an abandoned shoreline}

Lake Lahontan was a large pluvial lake that occupied most of the intramontane basins in northwest Nevada and adjacent northeast
California during the last glacial time (Benson et al., 1990, 1995) (Fig. 1). The Jessup embayment is a small identation located in the northwestern Carson Sink of the Lahontan Lake basin. The majority of surface lacustrine features in the embayment, including the highstand gravel barriers, date from the Sehoo lake cycle that receded from its $1338.4 \mathrm{~m}$ highstand at about $13.07 \pm 0.07{ }^{14} \mathrm{C} \mathrm{ka}$ (Adams and Wesnousky, 1998), or a calibrated calendar age of $15.22 \pm 0.12 \mathrm{ka}$ 

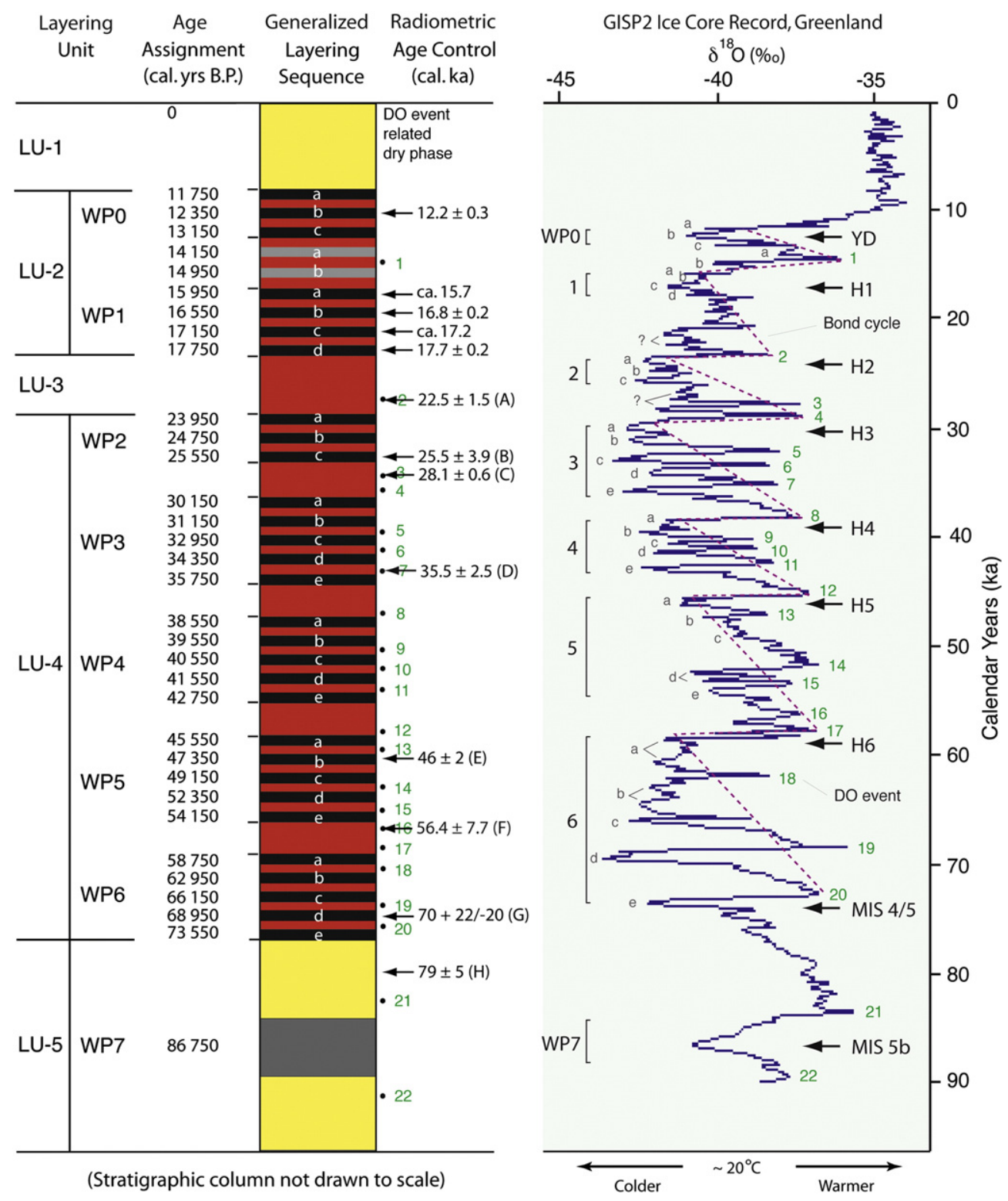

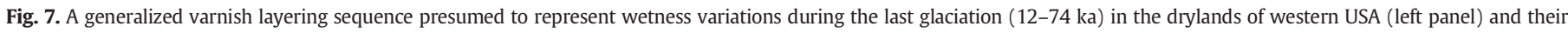

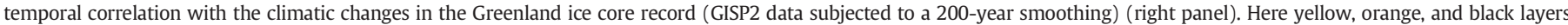

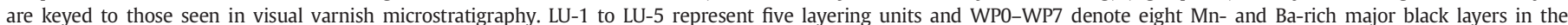

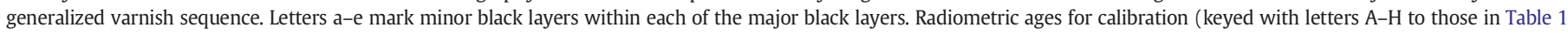

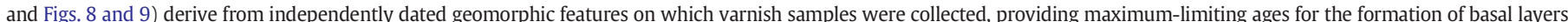

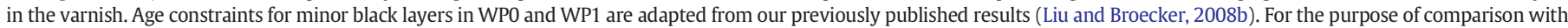

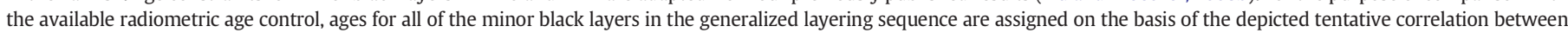

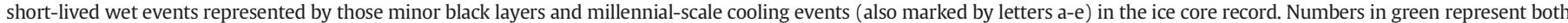

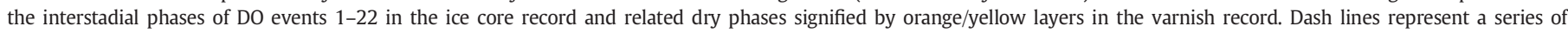

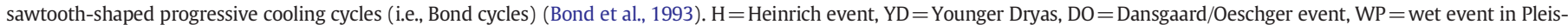
tocene, MIS = Marine Isotope Stage.

(Fairbanks et al., 2005). This age is based on an AMS radiocarbon date from camel bones found in a former lagoon enclosed behind a highstand barrier referred to as the Jessup playette barrier (Fig. 11B, C). The bones were found at the contact between lagoonal sands and primarily subaerial sediment that filled the closed depression after the lake had receded from the highstand. Thus, the age of the bones closely marks the beginning of the recession of Lake Lahontan from its Sehoo highstand (Adams and Wesnousky, 1998).

Debris flow deposits outcrop at a site along the shoreline piedmont slope west of the Jessup playette barrier (Fig. 11A, C), mantling the abandoned recessional shorelines just below the Sehoo highstand.
The deposits contain basaltic boulders coated with rock varnish. One sample was collected from the top face of a debris flow boulder on the abandoned shorelines (Fig. 11C). Varnish ultra-thin sections reveal a well-defined latest Pleistocene microstratigraphy. The oldest layering sequence found was $\mathrm{LU}-1 / \mathrm{LU}-2(\mathrm{WPO}+\mathrm{b}+)$ (i.e., layering sequence LU-1 through LU-2 with basal layer WP0 + b+) (Fig. 11D, E; also see Liu, 2003, for more detail on terminology). Based on the VML age scale in Fig. 7, the basal orange layer WPO $+b+$ in this varnish sample started to accumulate sometime between 14.95 and $15.95 \mathrm{ka}$. This is thus a minimum surface exposure age for the emplacement of the debris flow deposits (Fig. 11). Because the debris flow deposits postdate 
the abandonment of the recessional shorelines, the VML age estimate is also interpreted to yield a minimum-limiting age for the recession of Lake Lahontan. Given a lag time of $\sim 200$ years for varnish accumulation on subaerially exposed rock surfaces in this region (Liu and Broecker, 2007), the lower limit of the modified VML age estimate (15.15 ka) is quite close to the calibrated ${ }^{14} \mathrm{C}$ age of $15.22 \pm 0.12$ ka for the lake recession. Notably, the varnish microstratigraphy contains a basal orange layer $(\mathrm{WPO}+\mathrm{b}+$ ) that is diagnostic of a dry regime (Broecker and Liu, 2001), consistent with the fact that Lake Lahontan had recently receded from its Sehoo highstand.

\subsection{Meteor impact event}

Barringer Meteor Crater is located $69 \mathrm{~km}$ east of Flagstaff in northern Arizona at an elevation of about $1740 \mathrm{~m}$ (Figs. 1 and 12A). It is a big bowl-shape pit, about $170 \mathrm{~m}$ deep and $1.6 \mathrm{~km}$ in diameter, surrounded by a rim that rises some $45 \mathrm{~m}$ above the surrounding plains. The crater is geologically situated in the Canyon Diablo region of the southern part of the Colorado Plateau, underlain by Permian to Triassic sedimentary rocks of Coconino sandstone, Toroweap, Kaibab, and Moenkopi Formations (Shoemaker, 1987). The rim of the crater is blanketed by an overturned sequence of these sedimentary rocks ejected from the crater, which in turn is overlain by the late Pleistocene and Holocene alluvium. A number of large ejecta blocks, mostly of limestone and dolomite, sit on the rim of the crater, some standing 5-9 $\mathrm{m}$ above the ground and weighing over 700 tons (Fig. 12B). The lower walls and floor of the crater are covered by late Pleistocene and Holocene alluvial and colluvial deposits. Talus along the crater walls grades into alluvium on the floor of the crater, which in turn interfingers with a series of lake beds about $30 \mathrm{~m}$ thick. Underlying the lake deposits is the bottom breccia consisting primarily of angular pieces of sedimentary rock that were shattered during the impact (see Kring, 2007, for detailed geological descriptions of Meteor Crater).

The timing of the meteor impact event has been the subject of considerable research since its discovery in the late nineteenth century (Foote, 1891). Early studies (Barringer, 1905) suggested an age of 2$3 \mathrm{ka}$ for its formation. Based on surficial dissection of the crater, Tilghman (1905) gave an age estimate of not more than $10 \mathrm{ka}$ and probably less than $5 \mathrm{ka}$. Through careful evaluation of erosional features of the ravines and small graded valleys on the parapet of the crater and comparison of these erosional features with those on the Wisconsin (Tioga) glacial moraines in the Rocky Mountains, Blackwelder (1932) concluded that "the crater was made during the last interglacial (or post-Tahoe) epoch, perhaps 40,000 and 75,000 years old." Ives et al. (1964) reported a radiocarbon date of $24 \pm 2 \mathrm{ka}$ (or a calibrated calendar age of $28.77 \pm 2.39 \mathrm{ka}$ ) on gastropod shells collected from marl found on the dump of the main shaft at the floor of the crater, thus offering a minimum-limiting age for the impact. Shoemaker and Kieffer (1974) estimated that the crater was made "a few tens of thousands of years ago" based on the "mid-Wisconsin age of the oldest sedimentary deposits on the rim and in the interior of the crater." Shoemaker (1983) later gave a numerical version of this age estimate as $20-30 \mathrm{ka}$ or $25 \pm 5 \mathrm{ka}$. Thermoluminescence ( $49 \pm 3 \mathrm{ka}$ ) (Sutton, 1985), cosmogenic ${ }^{10} \mathrm{Be}$ (49.2 $\pm 1.7 \mathrm{ka}$ ) (Nishiizumi et al., 1991) and cosmogenic ${ }^{36} \mathrm{Cl}$ methods ( $49.75 \pm 0.85 \mathrm{ka}$ ) (Phillips et al., 1991) then yielded more precise and accurate ages. Marrero et al. (2010) recently revised the previously reported ${ }^{36} \mathrm{Cl}$ date to $56.0 \pm 2.4 \mathrm{ka}$ based on reassessment of the same samples with modern analytical methods and updated ${ }^{36} \mathrm{Cl}$ production rate parameters.

In this study, we collected the oldest possible rock varnish from the largest ejecta blocks on the rim of the crater for VML dating. Unfortunately, most of the ejecta blocks do not support good varnish accumulation as they are composed of relatively soluble lithologies such as limestone (Dorn and Oberlander, 1982). Among a dozen large ejecta blocks examined in the field, Monument Rock of Kaibab silicified dolomite on the east rim of the crater (Barringer, 1910) hosts the best and probably the oldest varnish (Fig. 12B). The bare top of Monument Rock is about $4 \times 5 \mathrm{~m}^{2}$ in size, relatively flat and slightly tilted toward the southeast without any debris cover. We collected a sample from varnish patches near the southern edge of the monolith. All varnish-filled microbasins from the specimen display extremely fine microlaminations as well as a replicable layering sequence (Fig. 12C, D). The oldest layering sequence observed contains LU-1/.../LU-4 (WP5c) with basal black layer WP5c, suggesting a minimum-limiting VML age of 49.15 ka for the impact event. If a lag time of $\sim 200$ years is considered for varnish accumulation on the sampled ejecta block (Liu and Broecker, 2007), the modified VML age estimate of $49.35 \mathrm{ka}$ is remarkably consistent with the formerly reported ages of $49 \pm 3 \mathrm{ka}(\mathrm{TL}), 49.2 \pm 1.7 \mathrm{ka}\left({ }^{10} \mathrm{Be}\right)$, and $49.75 \pm$ $0.85 \mathrm{ka}\left({ }^{36} \mathrm{Cl}\right)$ and slightly younger than the recently revised ${ }^{36} \mathrm{Cl}$ age of $56.0 \pm 2.4 \mathrm{ka}$ for the impact event.

We should note that this same Monument Rock was also previously dated by both ${ }^{10} \mathrm{Be}$ and ${ }^{36} \mathrm{Cl}$ methods, yielding surface exposure ages of $30.7 \pm 2.3 \mathrm{ka}$ and $36.5 \pm 1.15 \mathrm{ka}$, respectively (Nishiizumi et al., 1991; Phillips et al., 1991). Both ages would be $10-15 \%$ older if new ${ }^{10} \mathrm{Be}$ and ${ }^{36} \mathrm{Cl}$ production rates were used (Marrero et al., 2010; Putnam et al., 2010). These ages are anomalously younger than the formerly reported mean ${ }^{10} \mathrm{Be}$ age of $49.2 \pm 1.7 \mathrm{ka}$ and ${ }^{36} \mathrm{Cl}$ age of $49.75 \pm$ $0.85 \mathrm{ka}$ from other dated ejecta blocks and also the VML age of $49.15 \mathrm{ka}$ for the cratering event. Based on an erosion rate of $30 \mathrm{~cm} / \mathrm{ky}$ established at Whale Rock (the largest and tallest ejecta block on the north rim), Nishiizumi et al. (1991) estimated that the top of Whale Rock ( $49.2 \pm 1.7 \mathrm{ka})$ might have been exposed within a few thousand years after the crater was formed. They further speculated that exposure of the top of Monument Rock might have been delayed by an additional 10-15 ky, which likely led to its anomalously younger cosmogenic ages. Although the former seems reasonable, the latter is not consistent with our VML age data in several aspects. First, a $50-\mu \mathrm{m}$ layer of silica melt, inferred to have been formed by the meteor impact and observed beneath the varnish in ultra-thin sections (Fig. 12E), suggests that no erosion of the surface occurred prior to initiation of varnish accumulation. Thus, the VML age of 49.15 ka should be a minimum age for the impact event. Second, the VML age further implies that both Whale Rock and Monument Rock were exposed by the impacting event, or shortly thereafter, owing to their similar exposure ages (i.e., 49.15 ka vs. 49-56 ka), suggesting no delay as large as $10-15 \mathrm{ky}$ in the surface exposure of the top of Monument Rock. Third, the presence of only a few small patches of varnish on the edge of Monument Rock supports the possibility that much of the top may have been either covered by small ejecta, thus hindering varnish formation, or more susceptible to weathering, thus preventing formation of varnish. Fourth, the basal black layer WP5c in the varnish microstratigraphy (Fig. 12C, D) is diagnostic of a wetter-than-today climate in northern Arizona immediately after the impact event (Liu et al., 2000; Broecker and Liu, 2001), consistent with the lake sediments found in the crater bottom that directly overlie the impact breccia (Shoemaker, 1987). If a 10-15 ky delay in the exposure of Monument Rock were the case, the varnish microstratigraphies would exhibit a basal orange layer or a black layer of much younger age. Lastly, the top of Monument Rock is topographically a few meters above the top of another nearby large ejecta block (M-8), which was dated by Nishiizumi et al. (1991) at a much older ${ }^{10} \mathrm{Be}$ age of $40.7 \pm 5.5 \mathrm{ka}$. This is incompatible with the assumed uniform erosion of the crater rim (Nishiizumi et al., 1991).

We propose a speculative hypothesis to reconcile the VML and cosmogenic ages for Monument Rock. During or shortly after the impacting event (on a timescale of probably a few hundred years), the top of Monument Rock was exposed (like it is today) but still partly covered by some stand-alone, boulder-sized ejecta; the edges, however, were exposed and ready for varnish accumulation. Given the nature of the talus surrounding Monument Rock, and given the nature of fracturing in the Kaibab limestone, former covering stones 
Table 2

Characteristics and interpretation of the generalized late Pleistocene millennial-scale varnish layering sequence in the drylands of western USA.

\begin{tabular}{llll}
\hline LU & Black & Generalized & Characteristics and climatic interpretation of layering unit (LU) \\
number & layer & layering unit
\end{tabular}

LU-1

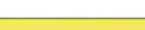

-1

WPO

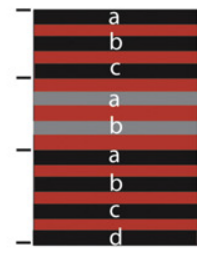

LU-2

WP1

LU-3

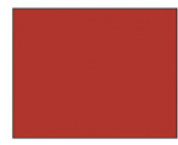

WP2

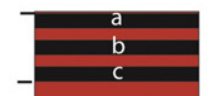

LU-1 is an outermost layering unit in a given varnish microstratigraphy and often contains one relatively thick, $\mathrm{Mn}$ - and Ba-poor yellow layer, reflecting the overall dry climate of the current Holocene interglacial. In some fast accreting varnish, LU-1 consists of 12 approximately evenly spaced weak minor black layers (WH1-12), diagnostic of Holocene millennial-scale wet phases (Fig. 4; Liu and Broecker, 2007). The overall thickness of LU-1 is largely affected by varnish accretion rate and surface erosion, varying from 5-30 $\mu \mathrm{m}$ on late Pleistocene varnish to 20-100 $\mu \mathrm{m}$ on latest Pleistocene and Holocene varnish.

LU-2 occurs immediately underneath LU-1 and often contains two major Mn- and Ba-rich black layers (WPO and WP1) separated by one thin Mn- and Ba-intermediate orange layer (WPO+). In fast accreting varnish, WP0 and WP1 contain 3 and 4 evenly spaced minor black layers, respectively, and WP0+ contains 2 relatively weak minor black layers, all indicative of terminal Pleistocene millennial-scale wet events in the western USA drylands (Liu and Broecker, 2008b). In particular, wet events represented by WPO and WP1 black layers correspond broadly in time with the YD and $\mathrm{H} 1$ cooling events (Fig. 3). In some cases, LU-2 unit is partly or completely missing in late Pleistocene varnish owing to post-depositional erosion (Figs. 6F,13D). Its thickness ranges from 0 to $40 \mu \mathrm{m}$.

LU-3 occurs as a single Mn- and Ba-intermediate orange layer that separates LU-2 from LU-4, diagnostic of the relatively dry climate during the glacial-to-interglacial transition. In slightly thick ultra-thin sections, 2 extremely weak minor black layers may be observed in LU-3, representing millennial-scale wet events likely coeval with the cooling events in the GISP2 $\delta^{18} \mathrm{O}$ record (labeled with a question mark "?" in Figs. 7, 8F). In some cases, both LU-2 and LU-3 are completely removed from varnish microstratigraphy by post-depositional erosion, leading to a direct contact between LU-1 and LU-4 (Fig. 6E). The overall thickness of LU-3 ranges from 0 to $20 \mu \mathrm{m}$.

LU-4 is the most prominent layering unit in varnish from the drylands of western USA and often contains 5 approximately evenly spaced major Mn- and Ba-rich black layers (WP2-6) separated by 4 minor Mn- and Baintermediate orange layers. Each of these major black layers further consists of 3-5 roughly evenly spaced minor black layers, representing short-term wet events correlated in time with millennial-scale cooling events in the GISP2 $\delta^{18} \mathrm{O}$ record (Fig. 7). The orange layers represent relativey dry phases after each wet event, and some of them are closely correlated in time with the warm phases of DO events in the GISP2 $\delta^{18} \mathrm{O}$ record (Fig. 7). The minor orange layers within each major black layer are usually much thinner than their neighboring minor black layers probably due to post-depositional erosion, making LU-4 visually compacted as a series of major black layers (Figs. 2B, 6E, F). In most cases, WP2 and WP3 black layers are altered into orange layers by post-depositional chemical leaching (Figs. 8E, G); in some cases, nearly all of WP2-5 black layers are altered into orange layers (Fig. 8H). The basal black layer of LU-4 (i.e., WP6 in general or WP6e in specific) often directly overlies on a thick, Mn- and Ba-poor yellow layer (LU-5). In some well-polished ultra-thin sections of very finegrained $(<1 \mu \mathrm{m})$ varnish, 2 relatively weak minor black layers may be observed in the orange layer between WP2 and WP3 black layers, representing 2 short-term wet phases likely coeval with the millennial-scale cooling events in the GISP2 $\delta^{18} \mathrm{O}$ record (labeled with a question mark "?" in Figs. 7, 8F). WP2-WP6 black layers each occassionally contain only 2-4 minor black layers owing to their post-depositional erosion or chemical leaching (Figs. 6E, F). In some fine-grained fast accreting varnish, each of these minor black layers may further contain 2-5 extremely thin black bands (Figs. 8D, 14D), indicative of submillennial or centennial-scale wet events. Note that 5 well-defined and evenly spaced minor black layers in WP5 represent 5 short-term wet phases in the western USA drylands, but their possibly associated cooling events in the GSIP2 $\delta^{18} \mathrm{O}$ record appear to be less-defined in both number and magnitude (Fig. 7). The overall thickness of LU-4 is about $40-130 \mu \mathrm{m}$.

LU-5 is a thick, $\mathrm{Mn}$ - and Ba-poor yellow layer overlain by a series of major black layers in LU-4. It is optically and chemically similar to the surface yellow layer of LU-1(Figs. 2B, C), thus representing the dry period of the last interglacial (MIS 5). One major black layer (WP7) is often observed in the upper part of LU-5, indicating a wet period associated with the cooling phase of MIS $5 \mathrm{~b}$ (Fig. 7). The overall thickness of LU-5 is about 2-60 $\mu \mathrm{m}$.

and their physical spalling could have shielded the cosmogenic collection site. Because humans have a propensity to roll precariously perched boulders, it is conceivable that an anthropogenic activity could be involved in removal of the covering stones. Thus, such unrecognized long-term shielding from these once stand-alone, boulder-sized ejecta on the top face led to the observed anomalously younger cosmogenic ages for Monument Rock. This hypothesis also offers a simple explanation for the $\sim 6 \mathrm{ky}$ age difference between $30.7 \pm 2.3 \mathrm{ka}\left({ }^{10} \mathrm{Be}\right)$ and $36.5 \pm 1.15 \mathrm{ka}\left({ }^{36} \mathrm{Cl}\right)$ for the same top face of Monument Rock. A test of our hypothesis would be to sample the varnished patches of Monument Rock for cosmogenic dating which should yield an age of $\sim 49.3 \mathrm{ka}$.

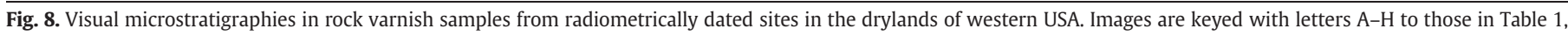
Figs. 7 and 9 (see Fig. 7 and text for terminology and layering pattern interpretation of these varnish microstratigraphies). 


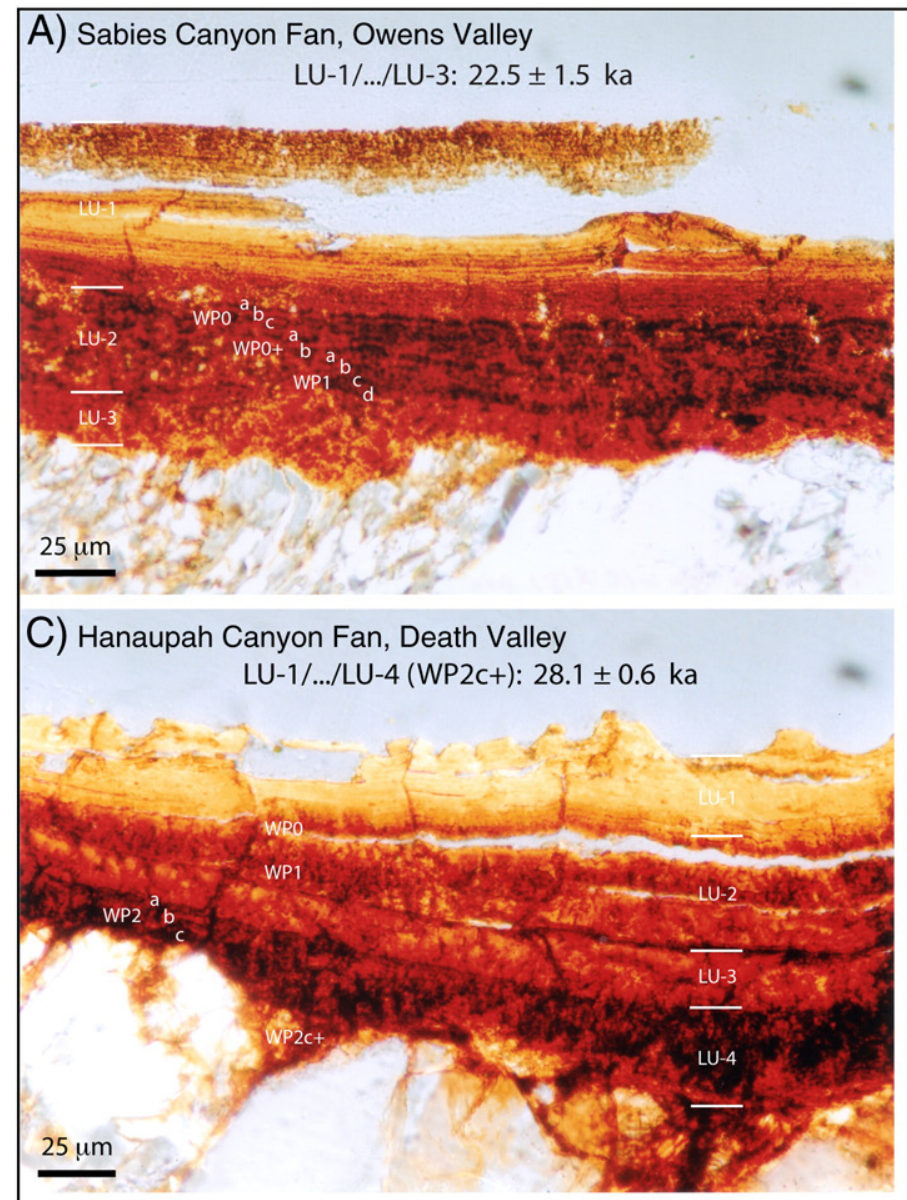

B) Unnamed East-side Fan, Death Valley

LU-1/.../LU-3: $22.5 \pm 1.5$ ka

LU-1/.../LU-4 (WP2c): $25.5 \pm 3.9 \mathrm{ka}$

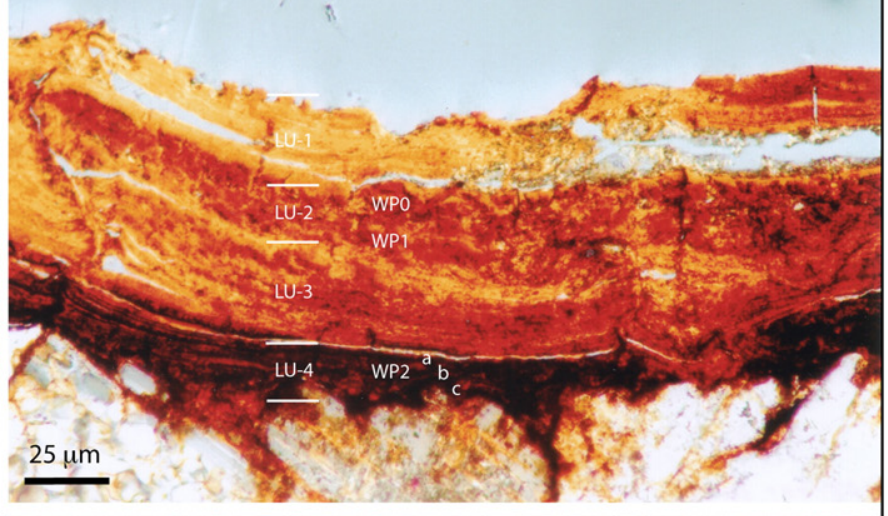

D) Biskra Palms Fan, Indio Hills

LU-1/.../LU-4 (WP3d+): $35.5 \pm 2.5$ ka

E) Cima Lava Flow, Mojave Desert

LU-1/.../LU-4 (WP5b): $46 \pm 2$ ka

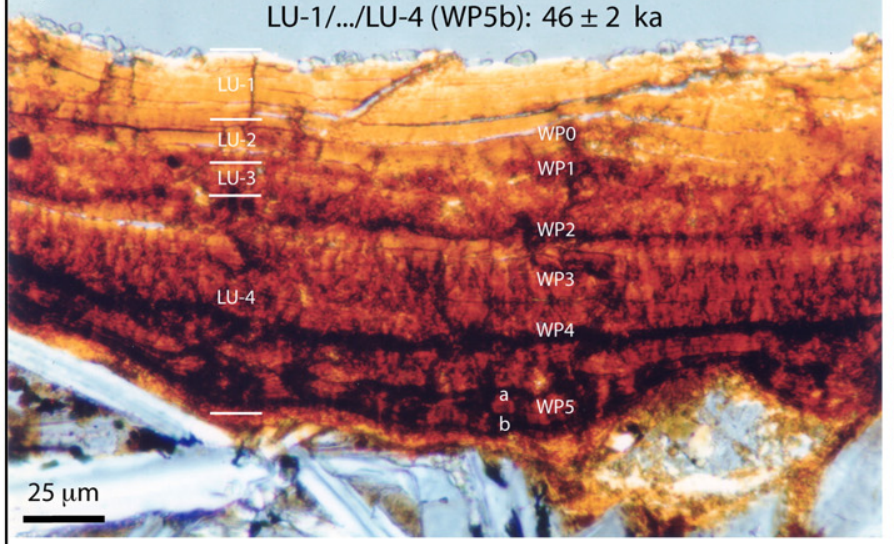

G) Red Wall Canyon Fan, Northern Death Valley LU-1/.../LU-4 (WP6d): $70+22 /-20$ ka 7 .

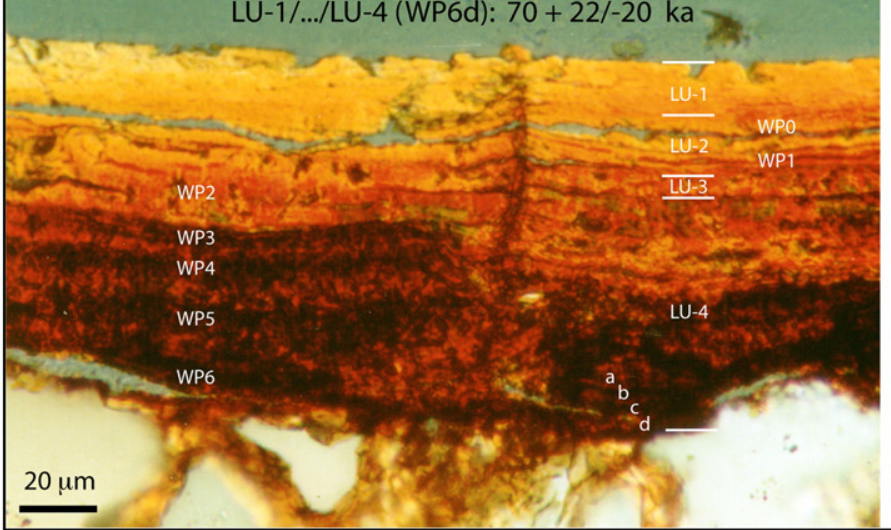

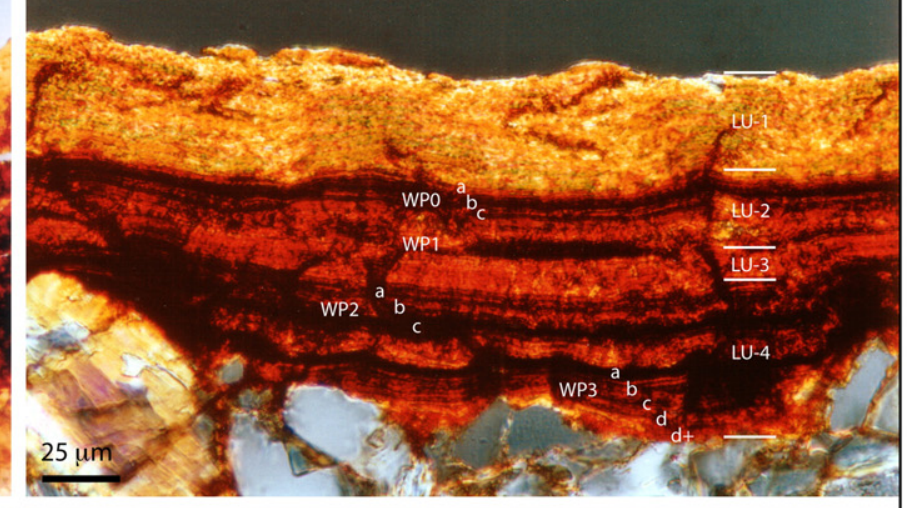

F) Sheep Springs Canyon Fan, Rodman Mountains

LU-1/.../LU-4 (WP5e+): $56.4 \pm 7.7$ ka

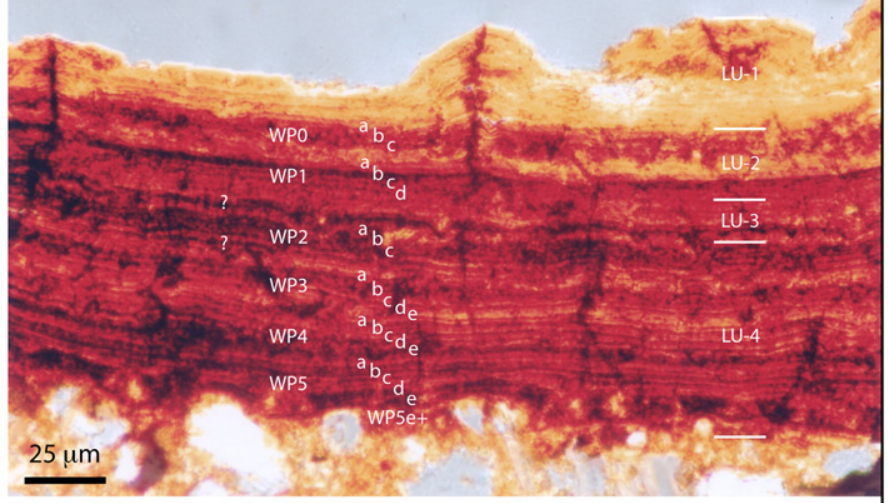

H) Amboy Lava Flow, Mojave Desert

LU-1/.../LU-5 (WP6e+): $79 \pm 5$ ka

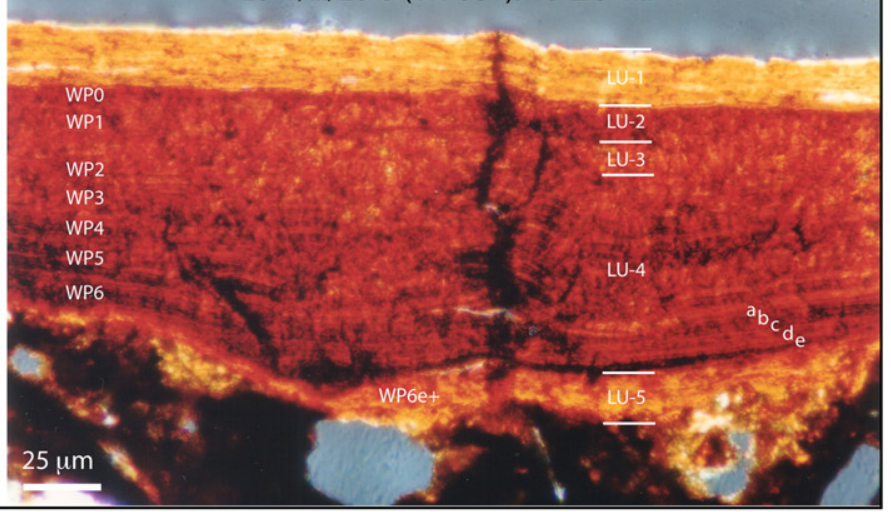



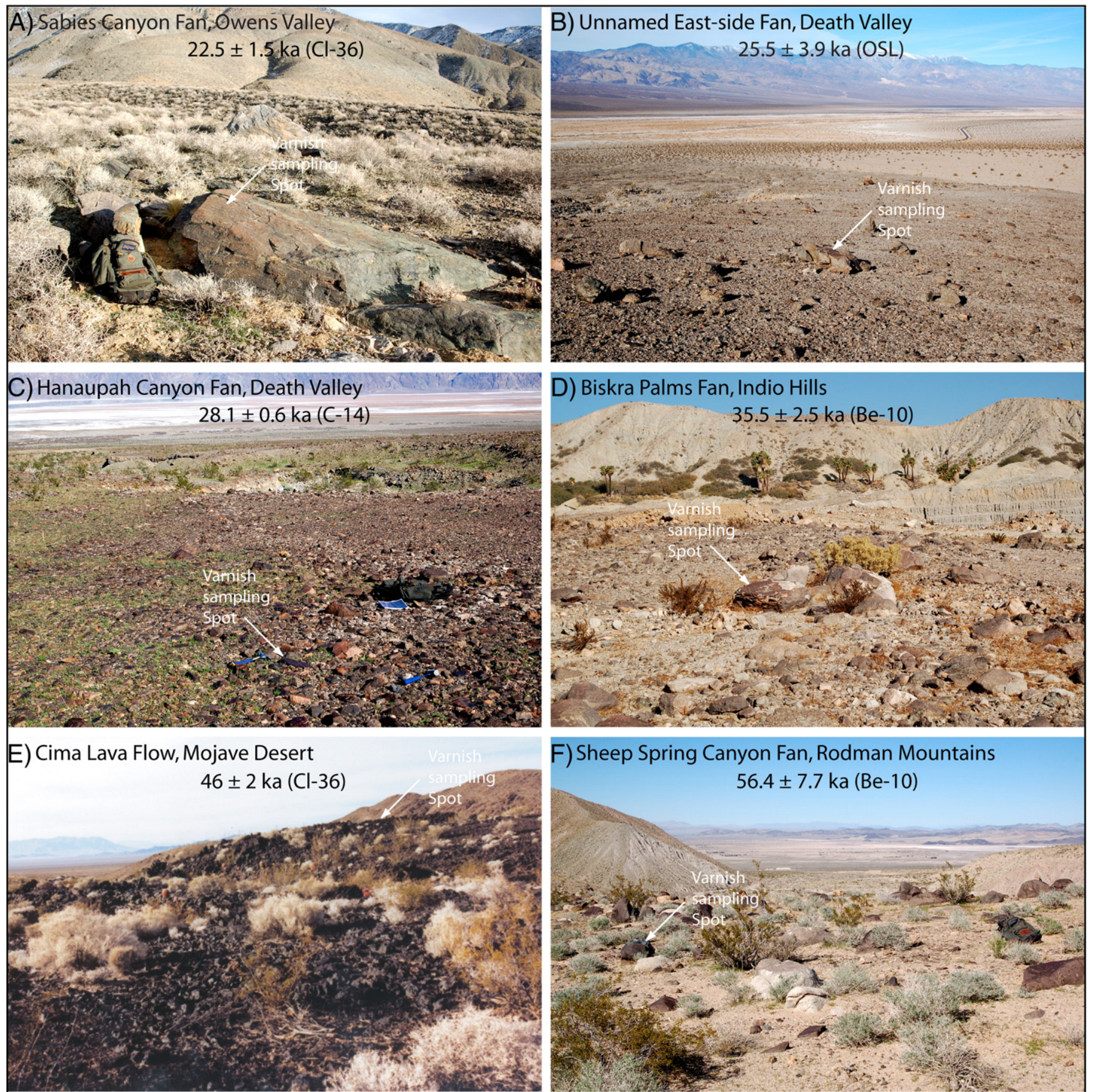

E) Cima Lava Flow, Mojave Desert

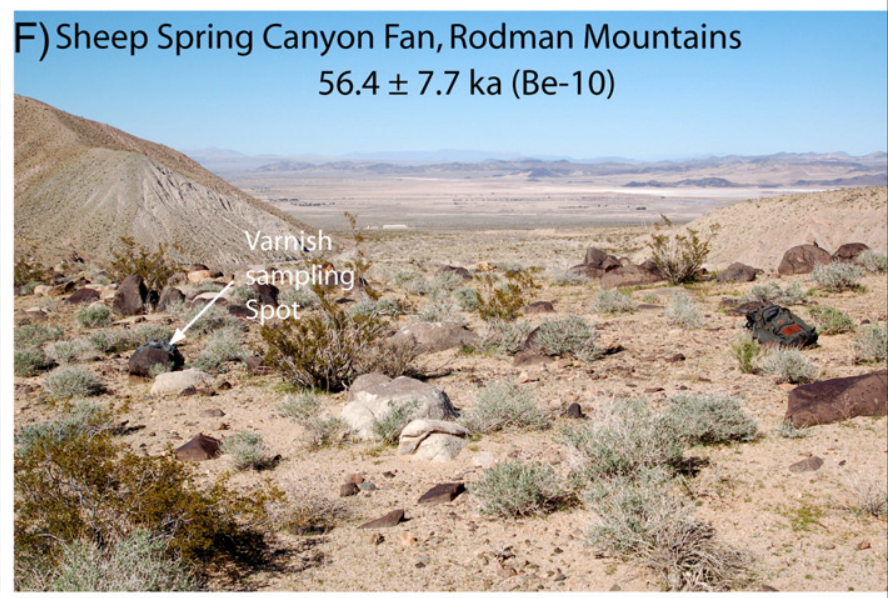

G) Red Wall Canyon Fan, Northern Death Valley $70+22 /-20 \mathrm{ka}(\mathrm{Be}-10)$

H) Amboy Lava Flow, Mojave Desert $79 \pm 5 \mathrm{ka}(\mathrm{Cl}-36)$
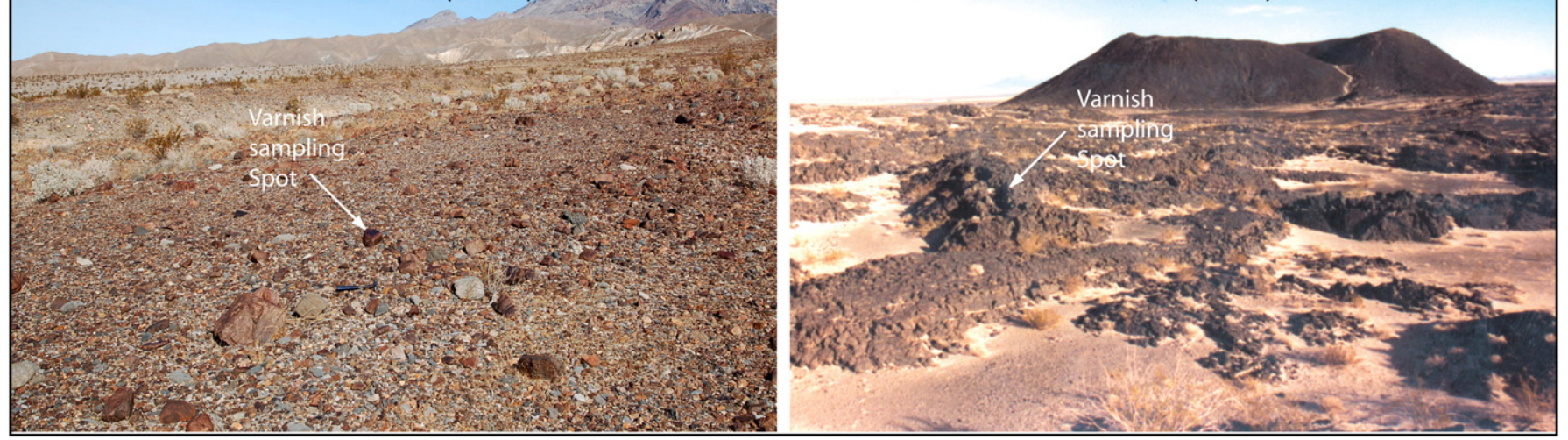

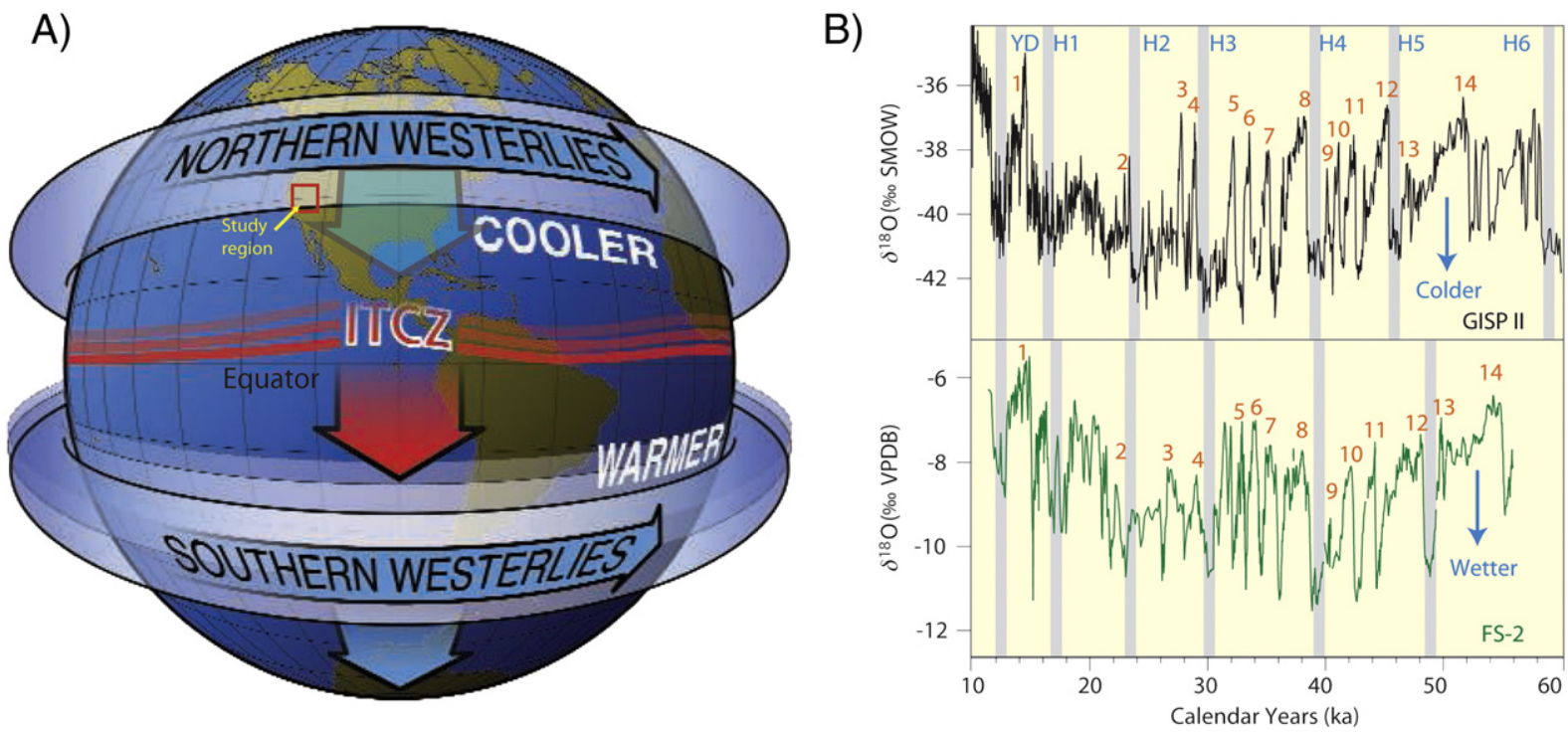

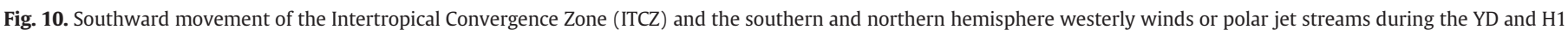

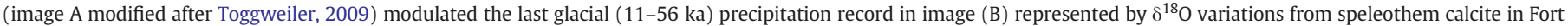

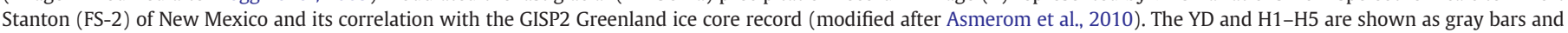

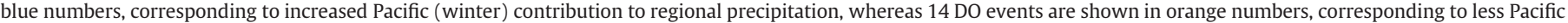
(winter) contribution.

\subsection{Cessation of fan aggradation}

Hanaupah Canyon alluvial fan is one of the best-developed and also most studied and mapped fans in Death Valley, eastern California (e.g., Denny, 1965; Hunt and Mabey, 1966; Denny, 1967; Hooke, 1972; Dorn, 1988; Bull, 1991; Hooke and Dorn, 1992). A recent study by Machette et al. (2008) remapped the fan surfaces into five different units, namely Qao, Qaio, Qai, Qayo, and Qay, on the basis of geomorphic position, surface morphology, soil characteristics, and available numerical age constraints (Fig. 13A). Qao is the oldest fan unit in the fan-head area, with typical ridge-and-ravine (ballena) topography and a suggested chronology of $>260 \mathrm{ka}$. Qaio is an older intermediate fan unit that is morphologically younger than Qao, with highly dissected desert pavement and a suggested chronology for mapped surficial deposits of $150-220 \mathrm{ka}$. Qai is an intermediate fan unit with well-developed desert pavement and a suggested chronology for mapped surficial deposits of 40-100 ka. Qayo and Qay are the youngest fan units that encompass channel deposits with older surface exposure ages (12-30 ka) and younger ages (0-12 ka), respectively.

As the aerially most extensive of the five mapped fan units on Hanaupah Canyon fan, Qai alluvium covers nearly the entire northern half of the fan surface, likely representing one of the most extensive episodes of fan aggradation during the late Pleistocene. A qualitative examination of high resolution Google Earth ${ }^{\circledR}$ imagery (Fig. 13B) suggests the potential for differentiating different aggradational events in the last phases of accumulation of this fan unit. Machette et al. (2008) recently obtained minimum ages for the abandonment of Qai fan surfaces at the distal sites of Hanaupah Canyon fan by the cosmogenic ${ }^{36} \mathrm{Cl}$ depth-profile method (Phillips et al., 2003). In their study, depth profile S12 on a morphologically older Qai fan surface (phase A) yielded a surface exposure age of $66+22 /-14 \mathrm{ka}$, whereas depth profile $\mathrm{S} 8$ on the same fan surface but about $500 \mathrm{~m}$ farther downfan yielded a much younger age of $39+19 /-15$ ka (Table 3; Fig. 13B). The difference is probably partly owing to post-depositional modification and erosion of the original fan surface (Machette et al., 2008). Depth profile S9 on an adjacent, morphologically younger Qai fan surface (phase B) yielded a slightly older age of $72+24 /-20 \mathrm{ka}$ (Fig. 13B). Taken together, the age for S12 overlaps with the age for S9 at the $1 \sigma$ confidence level, suggesting that the dated Qai fan surfaces at this specific location were broadly abandoned as sites of active deposition around $\sim 66-72 \mathrm{ka}$, or some kiloyears earlier, as creeping processes and weathering have modified the dated fan surfaces (Hooke, 1972). Considering issues of post-depositional modification, however, the phase B fan surface was likely abandoned at $\sim 72 \mathrm{ka}$, but the phase A fan surface could be formed shortly before $\sim 72 \mathrm{ka}$ because of its slightly older surface morphology and geomorphic position.

At the distal base of Hanaupah Canyon fan, the phase A Qai fan surface contains two topographically dominant side-by-side alluvial lobes, each 80-90 m wide, separated from each other by an $\sim 2-4 \mathrm{~m}$ deep gulley (just south of HC-1 and HC-3 in Fig. 13B). Smooth desert pavements have developed on both surfaces, and the soils include Av, Btkz, and Bz horizons with lots of silt and stages II-III carbonate (Machette et al., 2008). Some large alluvial boulders on these surfaces have been subjected to severe surface spalling owing to salt weathering, resulting in small patches of rubble covering the nearby ground. Morphologically younger Qai fan surfaces are either inset into or overlie the lower edges of the phase $A$ fan surface (Fig. 13B). Most boulders on the phase A fan surface are well varnished; only a few, however, retain fluvially polished smooth faces hosting the oldest possible varnish. After examining dozens of varnished boulders in the field, three varnish samples (HC-1, 2, 3 ) were collected from the phase A fan surface (Fig. 13B). Varnish ultra-thin sections reveal the same oldest layering sequence of LU-1/.../LU-4 (WP6e) with basal black layer WP6e, indicating a

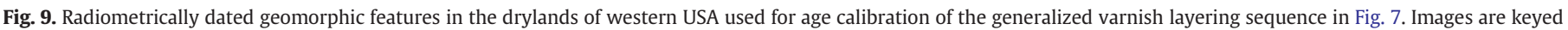
with letters A-H to those in Table 1, Figs. 7 and 8. The GPS coordinates, geomorphic context, and age sources of these sampling sites are given in Table 1. 
minimum-limiting VML age estimate of 73.55 ka for this surface (Fig. 13B; Table 3). This $73.55 \mathrm{ka}$ minimum age is largely consistent with the ${ }^{36} \mathrm{Cl}$ age of $\sim 72 \mathrm{ka}$ at S9 and within the $1 \sigma$ uncertainty of the $66+22 /-14$ ka age obtained at $\mathrm{S} 12$. While the resolution of the ${ }^{36} \mathrm{Cl}$ approach is insufficient to definitely conclude that the phase B surface postdates the phase A surface, the VML age indicates that the latter likely predates the former by a few kiloyears, consistent with relative geomorphic positions.

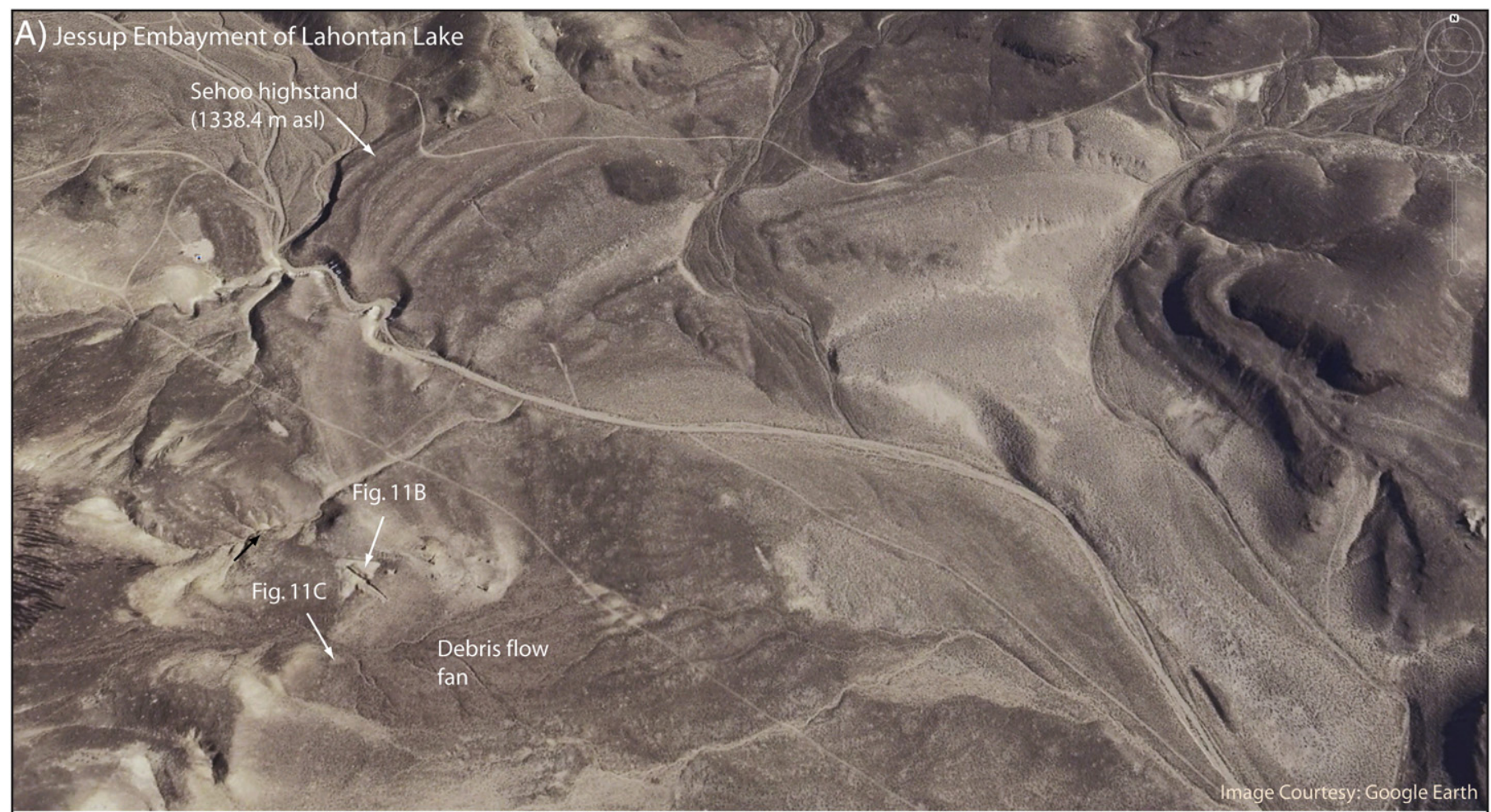

\section{B) A Lagoon behind the Jessup Playette Barrier}

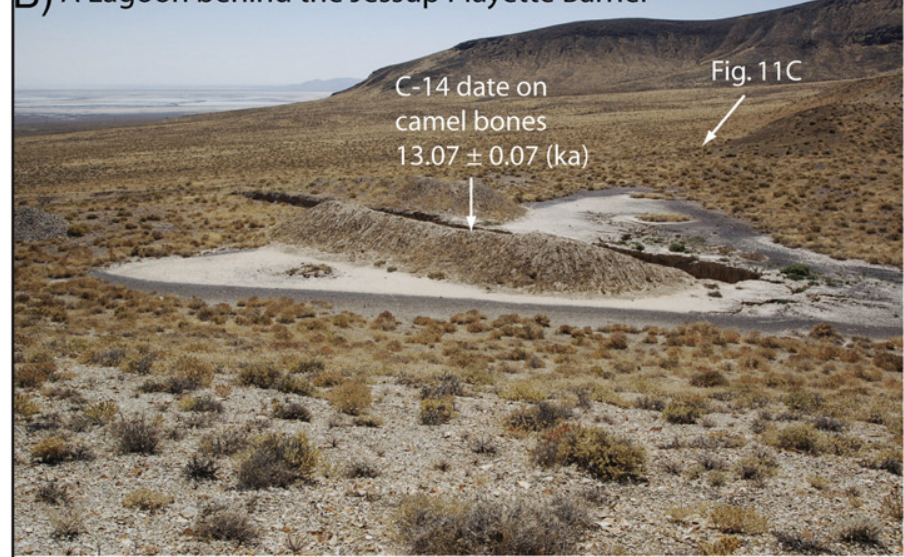

LU-1/.../LU-2 (WP0+b+): $14.95-15.95$ ka

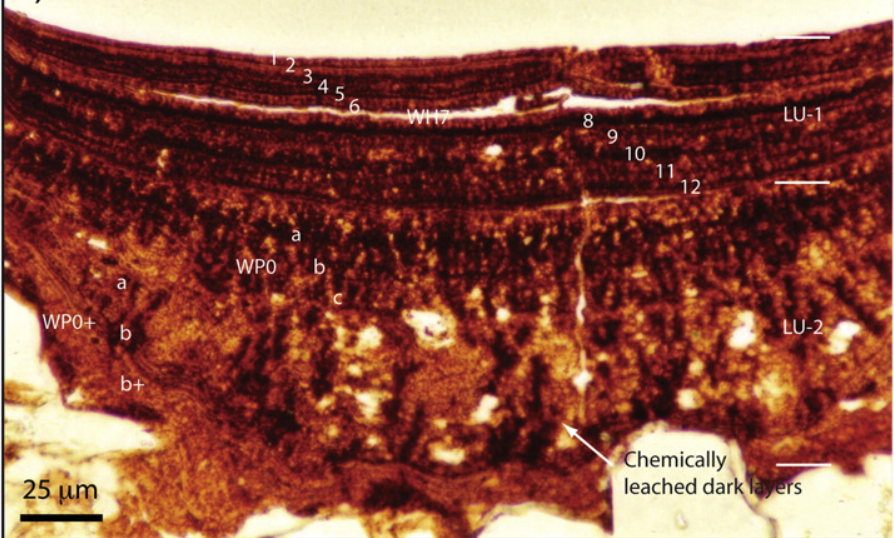

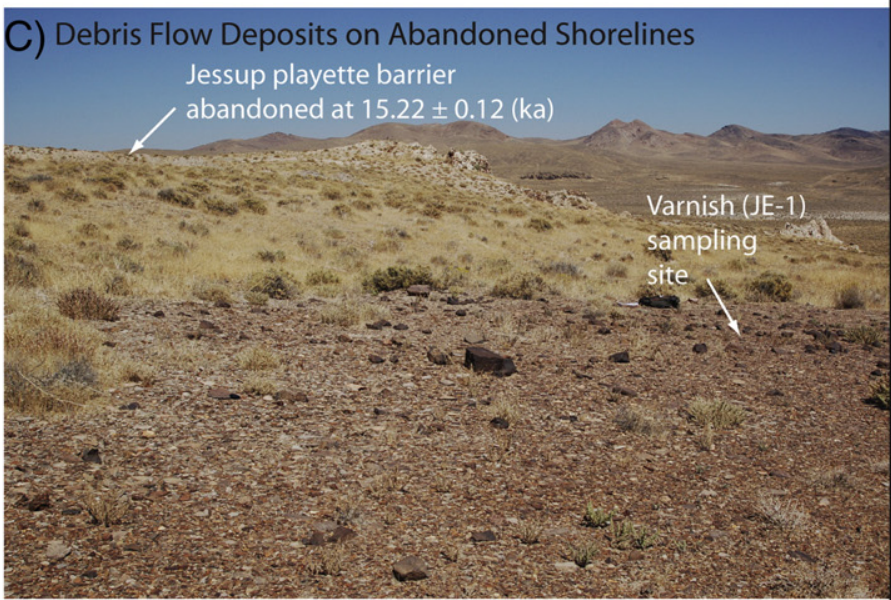

E) JE-1

LU-1/.../LU-2 (WP0+b+): $14.95-15.95$ ka

Chemically leached dark layers

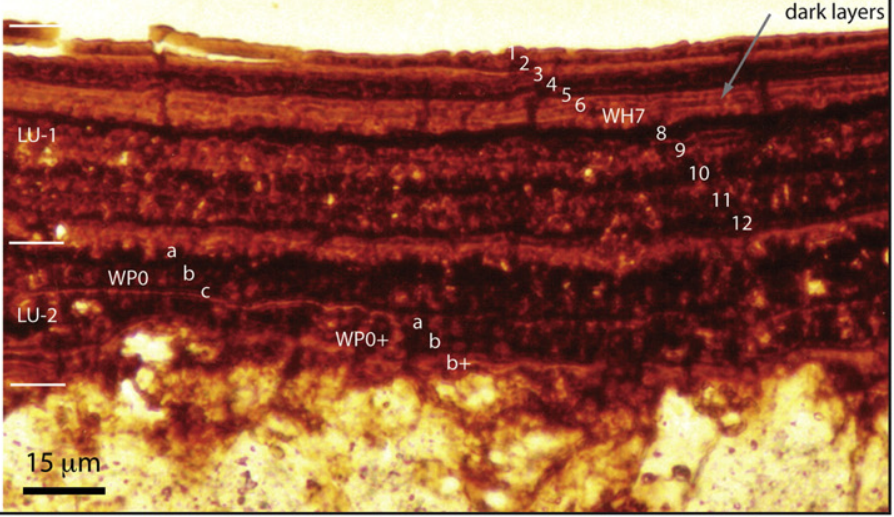




\subsection{Tributary fan formation}

A small-sized $\left(\sim 0.5-\mathrm{km}^{2}\right)$ tributary fan formed near the apex of Hanaupah Canyon fan south of the main trunk channel (Fig. 14A). It is bounded to the east by the ridge-and-ravine topography of unit Qao, and its toe directly overlies Qaio (Fig. 14A), suggesting that the last aggradation on the tributary fan postdates the last aggradation on the Hanaupah Canyon fan unit Qaio. Accordingly, tributary fan surfaces should date to $<150 \mathrm{ka}$ (Machette et al., 2008). Two episodes of fan aggradation are recognized on the basis of surface morphology and superposition. The early episode (phase I) produced the alluvial surface forming the western or upfan half of the fan, and the later one (phase II) created alluvial lobes forming the eastern or downfan half of the surface (Fig. 14A). The fan deposits consist mainly of unsorted quartz monzonite and limestone boulders and clasts of other lithologies derived from bedrock hills in the nearby small watershed draining to fan. Well-developed desert pavements dominate on the fan surfaces, with boulders and clasts coated with varnish.

Three samples were collected for VML dating, two (HC-4 and 5) on the phase I fan surface and the other (HC-6) on the phase II fan surface (Fig. 14A). Varnish ultra-thin sections of samples HC-4 and 5 reveal an oldest layering sequence of LU-1/.../LU-4 (WP6e+) with basal orange layer WP6e+, indicating a minimum-limiting VML age estimate of 73.55-86.75 ka for phase I. Because the basal yellow/ orange layer $(\mathrm{WP6e}+)$ in the varnish microstratigraphy is diagnostic of extremely dry climate (Broecker and Liu, 2001), this suggests that the phase I fan deposition ceased during a dry period shortly before the end of the last interglacial (MIS 5). Varnish ultra-thin sections of sample HC-6 contain the oldest layering sequence of LU-1/.../LU-4 (WP6c) with basal black layer WP6c, yielding a minimum-limiting VML age estimate of $66.15 \mathrm{ka}$ for cessation of deposition on the phase II fan surface. Since WP6c is indicative of a glacial wet climate (Broecker and Liu, 2001), this suggests that the phase II fan aggradation occurred during the wet period of MIS 4 when the northern hemisphere experienced a full glacial climate. The VML age estimates are in accord with the local geomorphic relation of the two dated fan surfaces; they are also consistent with the overall age assignment of 40-100 ka for unit Qai (Machette et al., 2008). These data suggest that deposition on this fan ceased somewhat after $\sim 66 \mathrm{ka}$. Cessation of deposition is almost certainly related to the phase of fanhead incision that led to abandonment of surface Qaio as a surface of active deposition, postdating the initiation of this incision by, probably, some tens of kiloyears. Hooke and Dorn (1992) place the initiation of this phase of incision at $\sim 190 \mathrm{ka}$ and Machette et al. (2008) at $~ 50 \mathrm{ka}$.

\section{Discussion}

\subsection{Uncertainties of VML age estimates}

As exemplified by the above case studies, VML dating can yield reliable, millennial-scale surface exposure ages for late Pleistocene and Holocene geomorphic features in the western USA drylands. However, VML age estimates have some intrinsic uncertainties that are attributed to the following factors:

(i) Sampling alluvial boulders that do not host the oldest possible varnish results in an underestimation of the age. Owing to the time-transgressive nature of varnish accumulation on subaerially exposed rock surfaces, the probability of collecting young varnish samples from old geomorphic surfaces is high. For example, spalling of weathering rinds on boulders can completely reset the varnish clock, leading to ages that are far younger than the landform.

(ii) Varnish-filled microbasins on a sample often host varnish microstratigraphies with various ages. Selecting those microbasins that do not contain the oldest basal varnish layer also leads to an underestimation of the age.

(iii) Varnish ultra-thin sections that are too thick $(>5-10 \mu \mathrm{m})$ to see millennial-scale microlaminations in the basal varnish layer result in VML age estimates with larger uncertainties, from submillennial age resolution for basal black layer WP6d (68.95 ka), for example, to sub-Milankovitch age resolution for basal black layer WP6 (58.75-73.55 ka).

(iv) Owing to the discrete distribution of age assignments on the VML age scale, the true age of a geomorphic surface also predetermines how accurate the VML age estimate could be for the surface. For instance, varnish from a geomorphic surface of late Holocene age displaying a basal orange layer $\mathrm{WH} 4+$ would yield a VML age estimate in a range of 2.8-4.1 ka (Fig. 4; cf. Liu and Broecker, 2007), whereas varnish from a surface of terminal Pleistocene age displaying a basal black layer WPOb would yield a single VML age estimate of $12.35 \mathrm{ka}$ (Fig. 5).

(v) Misinterpretation of layering patterns in varnish microstratigraphy often leads to either overestimated or underestimated VML ages.

(vi) Selecting samples from the most xeric microenvironments generates the slowest rates of varnish accretion, which in turn can yield sections with missing microlaminae. On the other hand, selecting samples from mesic microenvironments that are too wet promotes the growth of lithobiotic microorganisms that erode varnish and disturb VML patterns. The key rests in selecting microbasins in which varnish formation was rapid, but which have not been colonized by acid-producing organisms.

When properly applied, the millennial-scale VML dating generally yields surface exposure ages or age ranges with a resolution of $\sim 10^{2}-$ $10^{3}$ years for geomorphic features of late Pleistocene and Holocene age in the western USA drylands.

\subsection{Alluvial fan responses to millennial-scale climatic events}

A fundamental problem involved in the study of desert geomorphology is how environmental factors, especially climatic changes, influence alluvial fan development. One climatic model of alluvial fan development posits that fan aggradation occurred during wetter climates (e.g., DeLong et al., 2008; Armstrong et al., 2010; Fletcher et al., 2010). The climatic-transition model of alluvial fan development presumes that fan aggradation took place during climatic shifts from the glacial to interglacial state (e.g., Bull and Schick, 1979; Wells et al., 1987; Bull, 1991; Reheis et al., 2005). Although the climatic interpretation of alluvial fan development has many appealing elements, a direct correlation of fan aggradation events with millennial-scale climatic changes is often missing owing to lack of either wellconstrained age control on fan aggradation events or site-specific information on climatic conditions, or both.

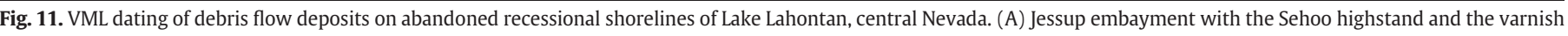

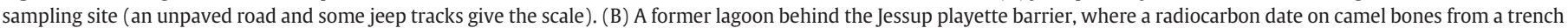

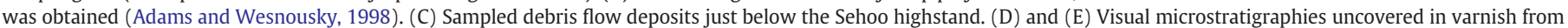

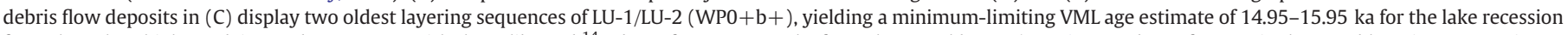

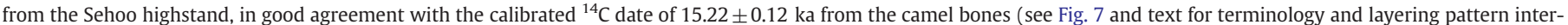

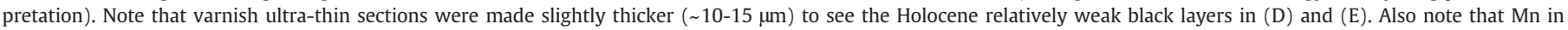

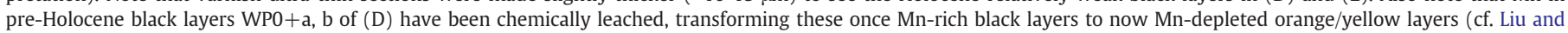
Broecker, 2007).
} 

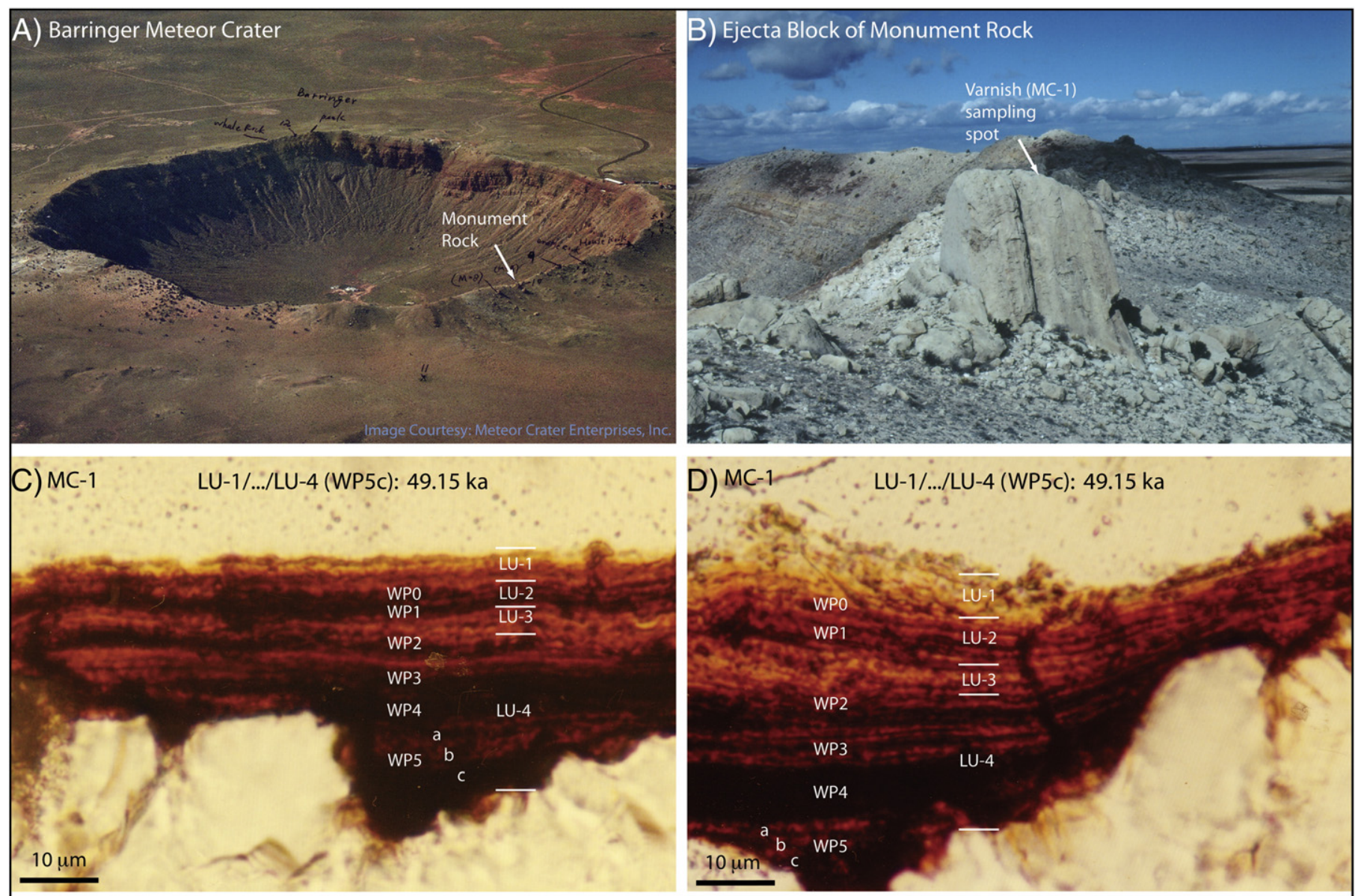

\section{E) Varnish from Monument Rock (MC-1)}

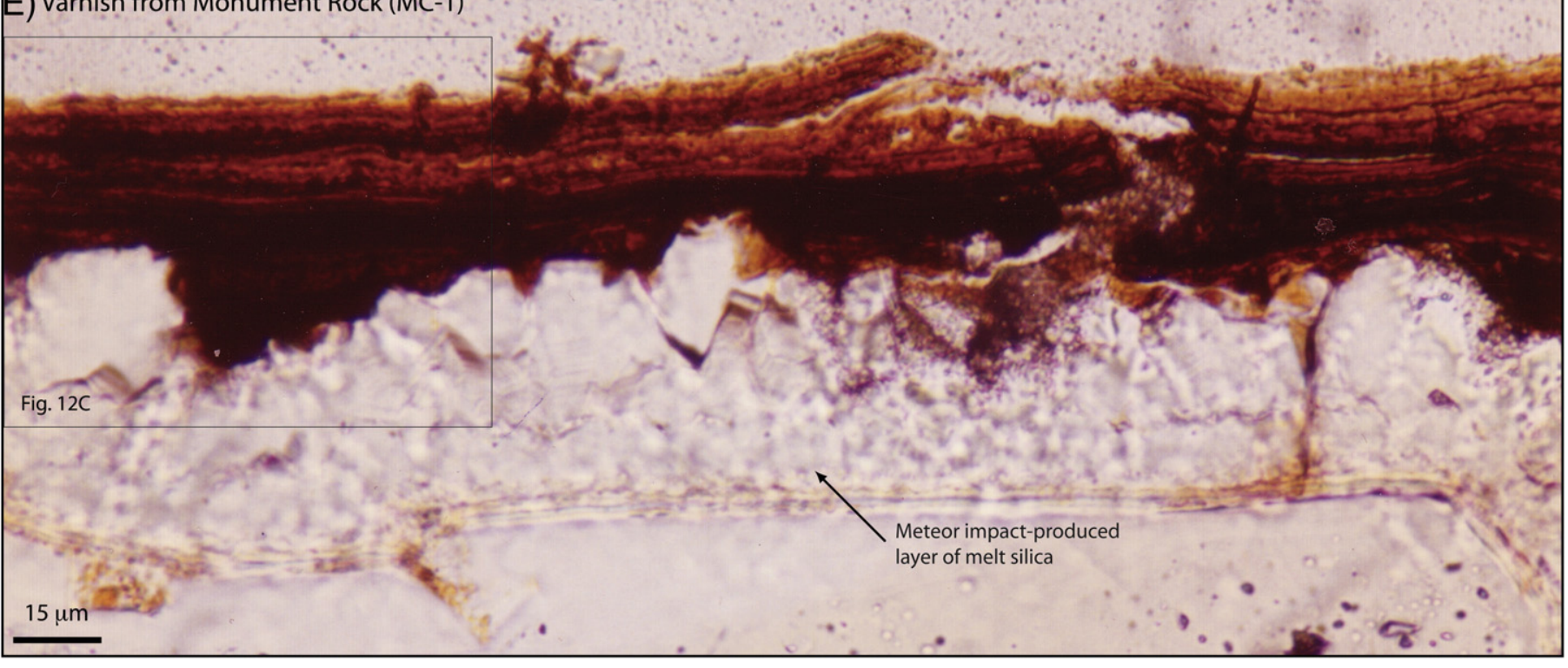

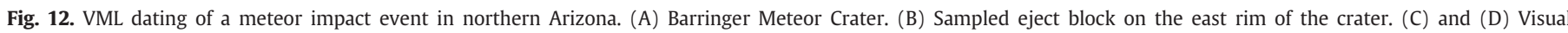

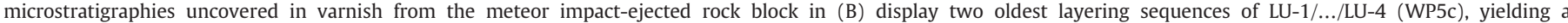

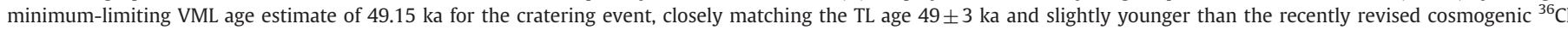

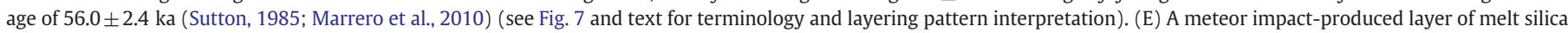
about $50-\mu \mathrm{m}$ thick underneath the varnish formation, indicating zero erosion of the sampled ejecta face and thus the oldest possible varnish formed on it.

The VML technique provides paleoenvironmental insight into the conditions of fan aggradation and a minimum age for the cessation of aggradation at a particular location. Thus, VML is especially suited for linking climate change to alluvial fan development in arid to semiarid lands. In the framework of millennial to sub-Milankovitch VML age calibration, fan aggradation appears to occur during wet and dry 

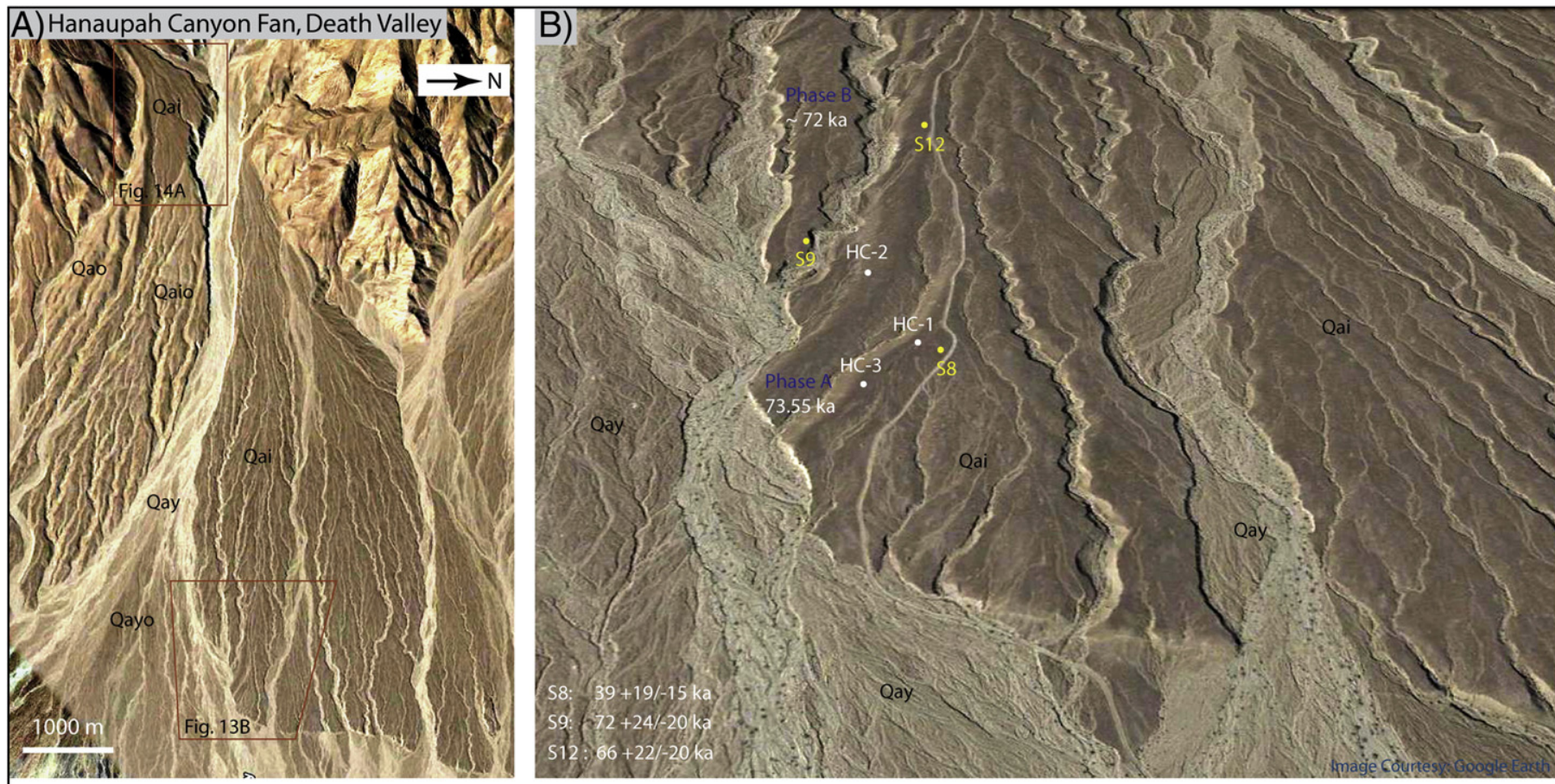

C) $\mathrm{HC}-1$

LU-1/.../LU-4 (WP6e): 73.55 ka

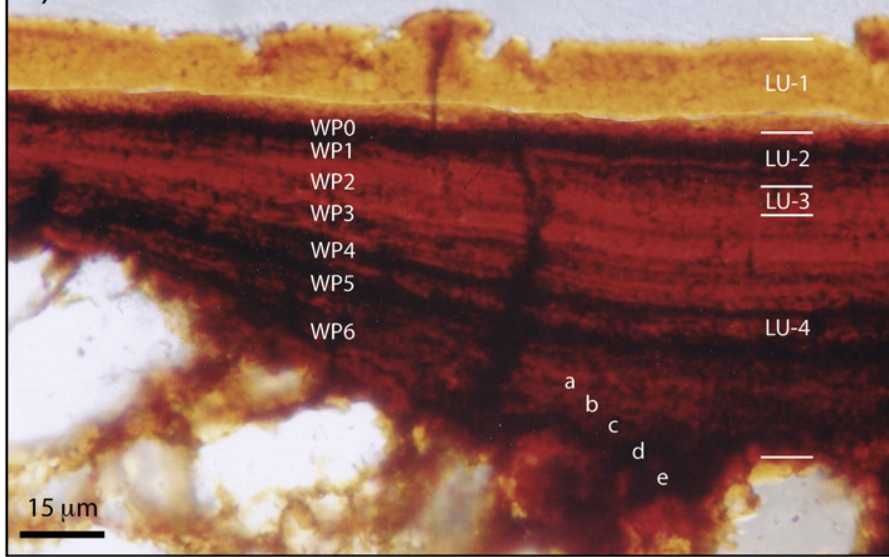

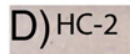

LU-1/.../LU-4 (WP6e): 73.55 ka

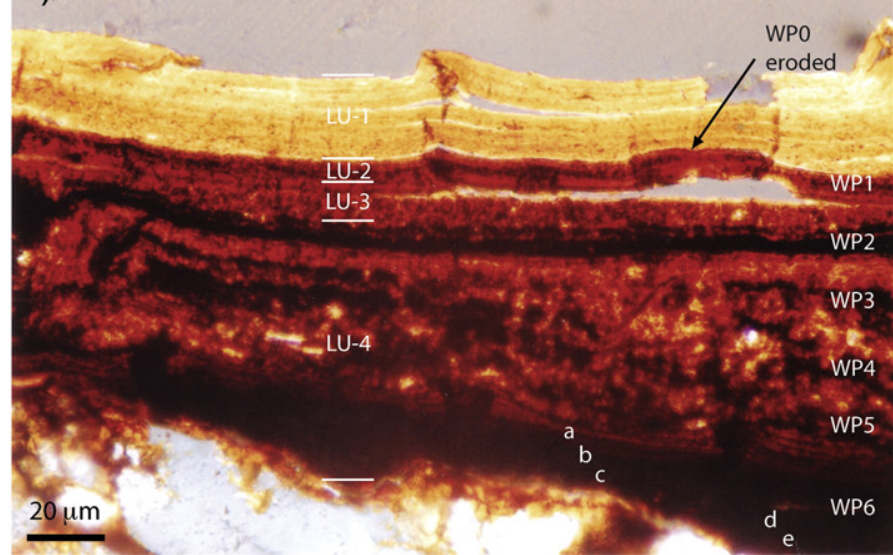

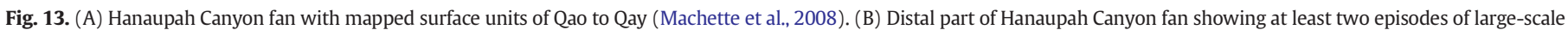

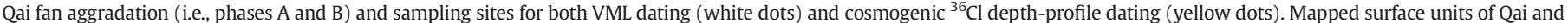

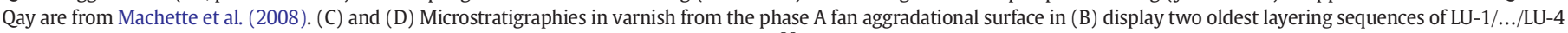

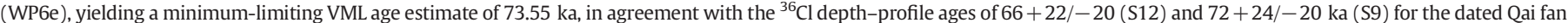

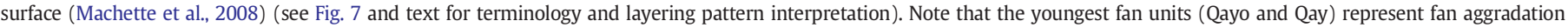

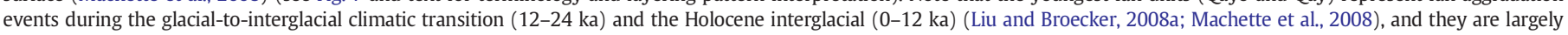
confined within the main trunk channel that entrenched into Qai and older fan units of Hanaupah Canyon fan, or emplaced at the fantoe.

intervals as Hooke and Dorn (1992) would argue. For instance, deposition of the phase I surface of the tributary fan in the fanhead area of Hanaupah Canyon fan ceased during a dry period of the last interglacial (MIS 5a) around $73.55-86.75 \mathrm{ka}$, whereas the phase II surface last aggraded during a wet period of the last glacial (MIS 4) around $66.15 \mathrm{ka}$ (Fig. 14A). Moreover, deposition of phase A materials on unit Qai on Hanaupah Canyon fan last occurred during a wet period of MIS 4 around $73.55 \mathrm{ka}$, and the base of this unit was likely also deposited during a wet period of MIS 6 (Hooke and Dorn, 1992). Furthermore, older channel fill deposits of unit Qayo (12-24 ka) on Hanaupah Canyon fan and on the tributary fan aggraded during the climatic transition period of late glacial time, and younger channel fill and active wash deposits of unit Qay (0-12 ka) aggraded during the Holocene (Figs. 13 and 14; Liu and Broecker, 2008a; Machette et al., 2008).
Thus, on the millennial to sub-Milankovitch timescale, fan aggradation appears to occur during wet periods, during dry periods, and during transitions from wet to dry or from dry to wet. This observation is consistent with the finding of numerous alluvial-fan studies in different regions of the world (e.g., wet periods: Ritz et al., 2003; Bhandari et al., 2005; Owen et al., 2006; dry periods: Chamyal et al., 2003; Hetzel et al., 2004; Pope and Wilkinson, 2005; transitions from wet to dry: Carignano, 1999; Klinger et al., 2003; transitions from dry to wet: Roberts and Barker, 1993; Eriksson et al., 2000; Jain and Tandon, 2003; Al Farraj and Harvey, 2004). This observation is also concordant with the undeniable fact that rain falls and runoff occurs under various climatic conditions. Regardless of prevailing climatic conditions, however, fanhead incision would not happen without former fan aggradation in the first place. Therefore, it is probably the decreases in 
Table 3

Millennial-scale VML age dating of late Pleistocene geomorphic features in the western USA drylands.

\begin{tabular}{|c|c|c|c|c|c|c|}
\hline Sample site and label & $\begin{array}{l}\text { Latitude }(\mathrm{N}) / \\
\text { longitude }(\mathrm{W})\end{array}$ & $\begin{array}{l}\text { Oldest layering pattern } \\
\text { observed }\end{array}$ & $\begin{array}{l}\text { VML age } \\
\text { estimate (ka) }\end{array}$ & $\begin{array}{l}\text { Type VML } \\
\text { image }\end{array}$ & Reference age (ka) & Geomorphic context and reference \\
\hline \multicolumn{7}{|l|}{ Jessup embayment } \\
\hline \multicolumn{7}{|l|}{ Lake Lahontan, Nevada } \\
\hline \multirow[t]{2}{*}{ JE-1 } & \multirow[t]{2}{*}{$39^{\circ} 56^{\prime} 20.34^{\prime \prime} / 118^{\circ} 51^{\prime} 11.21^{\prime \prime}$} & LU-1/LU-2 (WP0+b+) & $14.95-15.95$ & Fig. 11D & \multirow{2}{*}{$\begin{array}{l}15.22 \pm 0.12 \\
\left({ }^{14} \mathrm{C}\right)\end{array}$} & \multirow{2}{*}{$\begin{array}{l}\text { Debris flow deposits on abandoned } \\
\text { shorelines (Adams and Wesnousky, } \\
\text { 1998) }\end{array}$} \\
\hline & & $\mathrm{LU}-1 / \mathrm{LU}-2(\mathrm{WPO}+\mathrm{b}+)$ & $14.95-15.95$ & Fig. 11E & & \\
\hline \multicolumn{7}{|l|}{ Barringer Meteor Crater } \\
\hline \multicolumn{7}{|l|}{ Arizona } \\
\hline \multirow[t]{3}{*}{ MC-1 } & \multirow[t]{3}{*}{$35^{\circ} 01^{\prime} 39.17^{\prime \prime} / 111^{\circ} 00^{\prime} 58.24^{\prime \prime}$} & LU-1/.../LU-4 (WP5c) & 49.15 & \multirow{3}{*}{$\begin{array}{l}\text { Fig. 12C } \\
\text { Fig. 12D }\end{array}$} & $49 \pm 3(\mathrm{TL})$ & \multirow{3}{*}{$\begin{array}{l}\text { Meteor impact-produced ejecta block } \\
\text { (Sutton, 1985; Nishiizumi et al., 1991; } \\
\text { Marrero et al., 2010) }\end{array}$} \\
\hline & & LU-1/.../LU-4 (WP5c) & 49.15 & & $49.2 \pm 1.7\left({ }^{10} \mathrm{Be}\right)$ & \\
\hline & & LU-1/.../LU-4 (WP5c) & 49.15 & & $56.0 \pm 2.4\left({ }^{36} \mathrm{Cl}\right)$ & \\
\hline \multicolumn{7}{|l|}{ Hanaupah Canyon fan } \\
\hline \multicolumn{7}{|l|}{ Death Valley, California } \\
\hline $\mathrm{HC}-1$ & $36^{\circ} 13^{\prime} 1.47^{\prime \prime} / 116^{\circ} 53^{\prime} 52.27^{\prime \prime}$ & LU-1/.../LU-4 (WP6e) & 73.55 & Fig. $13 C$ & $\begin{array}{l}39+19 /-15 \\
\left({ }^{36} \mathrm{Cl} ; \mathrm{S} 8\right)^{\mathrm{a}}\end{array}$ & \multirow{3}{*}{$\begin{array}{l}\text { Qai fan surface (Machette et al., 2008) } \\
\text { or Q2c fan surface (Bull, 1991); varnish } \\
\text { was collected from phase A fan deposits }\end{array}$} \\
\hline HC-2 & $36^{\circ} 12^{\prime} 59.00^{\prime \prime} / 116^{\circ} 54^{\prime} 0.60^{\prime \prime}$ & LU-1/.../LU-4 (WP6e) & 73.55 & Fig. 13D & $\begin{array}{l}66+22 /-14 \\
\left({ }^{36} \mathrm{Cl} ; \mathrm{S} 12\right)\end{array}$ & \\
\hline $\mathrm{HC}-3$ & $36^{\circ} 13^{\prime} 0.00^{\prime \prime} / 116^{\circ} 53^{\prime} 49.30^{\prime \prime}$ & LU-1/.../LU-4 (WP6e) & 73.55 & & $\begin{array}{l}72+24 /-20 \\
\left({ }^{36} \mathrm{Cl} ; \mathrm{S} 9\right)\end{array}$ & \\
\hline \multicolumn{7}{|l|}{ Tributary fan } \\
\hline \multicolumn{7}{|l|}{ Death Valley, California } \\
\hline $\mathrm{HC}-4$ & $36^{\circ} 12^{\prime} 17.08^{\prime \prime} / 116^{\circ} 57^{\prime} 52.95^{\prime \prime}$ & LU-1/.../LU-5 (WP6e+) & $73.35-86.75$ & Fig. $14 \mathrm{~B}, \mathrm{C}$ & 40-100 (Qai) & \multirow{3}{*}{$\begin{array}{l}\text { Qai fan surface (Machette et al., 2008) } \\
\text { or Q2c fan surface (Bull, 1991) }\end{array}$} \\
\hline HC-5 & $36^{\circ} 12^{\prime} 20.88^{\prime \prime} / 116^{\circ} 57^{\prime} 45.93^{\prime \prime}$ & LU-1/.../LU-5 (WP6e+) & $73.35-86.75$ & & 40-100 (Qai) & \\
\hline HC-6 & $36^{\circ} 12^{\prime} 11.56^{\prime \prime} / 116^{\circ} 57^{\prime} 52.67^{\prime \prime}$ & LU-1/.../LU-4 (WP6c) & 66.15 & Fig. 14D,E & 40-100 (Qai) & \\
\hline
\end{tabular}

a This reported ${ }^{36} \mathrm{Cl}$ depth-profiling age for phase A fan deposits may have been affected by post-depositional erosion of the dated fan surface (Machette et al., 2008).

magnitude and frequency of fan alluviation or the climatic shift from wet to dry, rather than the climatic state of wet or dry, that trigger fanhead incision and fantoe aggradation.

Because fan aggradation is primarily and ultimately controlled by the intensity and frequency of precipitation events and probably secondarily affected by bedrock weathering, sediment storage, and vegetation cover of fan-feeding drainage basin hillslopes (cf., Bull and Schick, 1979; Wells et al., 1987; Bull, 1991; Harvey et al., 1999; Reheis et al., 2005), the key modulation of fan aggradation likely involves millennial to sub-Milankovitch timescale major climatic changes such as Heinrich events, DO events, and glacial/interglacial shifts. These major climatic changes could be the pacemaker of regionally contemporaneous large-scale fan segmentation, wherever other factors such as regional tectonic settings and base levels remain unchanged. It is in this sense that the climatic interpretation of alluvial fan development is a promising model to help interpret alluvial fan evolution.

\section{Conclusion}

In this study, we establish a generalized late Pleistocene (18$74 \mathrm{ka}$ ) millennial-scale varnish microlamination sequence for the drylands of western USA, radiometrically calibrate the sequence, and climatically correlate it with the $\delta^{18} \mathrm{O}$ record in the GISP2 Greenland ice core. We then use this climate-correlated, millennial-scale varnish microstratigraphy to estimate surface exposure ages for late
Pleistocene geomorphic surfaces in the western USA. As exemplified by the case studies presented here and our previous research (Liu and Broecker, 2007), millennial-scale VML dating is capable of yielding high resolution $\left(\sim 10^{2}-10^{3}\right.$ years $)$ age estimates for various geomorphic features of late Pleistocene and Holocene age in the drylands of western USA. Although more research is still needed to refine the VML age scale, the overall climatic correlation of varnish microstratigraphy established in this study constitutes a basis for further advances of VML dating in other desert regions of the world (see the website of www.vmldating.com for details). Because varnish microlaminations carry both climatic and chronometric signals for the formation and evolution of desert landforms, the VML method allows geomorphologists to make climatic correlations and to obtain minimum ages on desert landforms. Millennial-scale VML thus allows analyses of how landforms respond to millennial-scale climatic events.

\section{Acknowledgments}

This research was supported by a Comer Science \& Education Foundation grant (CSEF-12169). The early phase of this research was funded by grants from the U.S. Department of Energy (DE-FG02-95ER14572). We thank Meteor Crater Enterprises for giving us permission to do field work and rock varnish sample collection at the crater. We also thank J.W. Bell, R.P. Dickerson, and D.M. Miller for the stimulating discussions on VML dating. We greatly appreciate F.M. Phillips for his collaboration

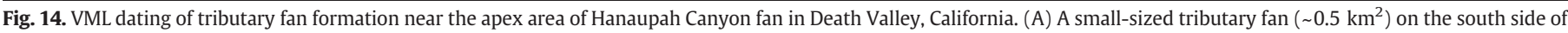

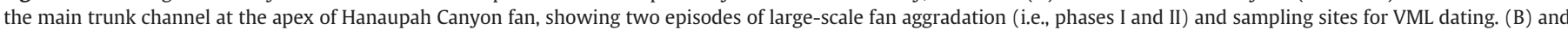

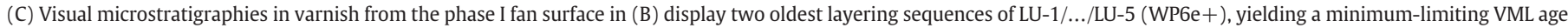

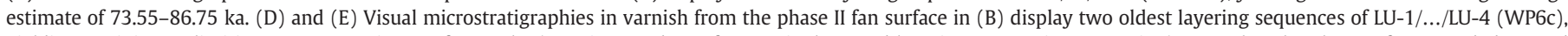

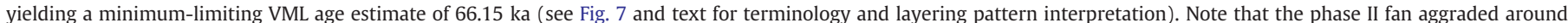

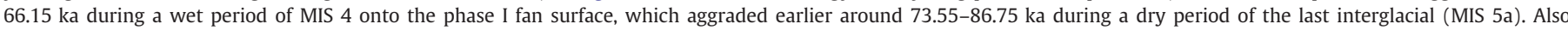

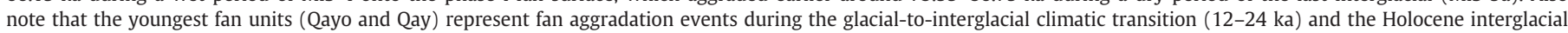
(0-12 ka) (Liu and Broecker, 2008a; Machette et al., 2008), and they are largely confined within the main trunk channel that entrenched into Qai unit of the tributary fan. 
on blind-testing of the VML method and long-term support. This paper benefited substantially from constructive comments and suggestions by R.LeB. Hooke, though the ideas expressed therein are our own. Critical reviews by J.L. Betancourt, W.B. Bull, and an anonymous reader, and editorial suggestions by R.A. Marston have considerably improved the manuscript. LDEO contribution no. 7637.

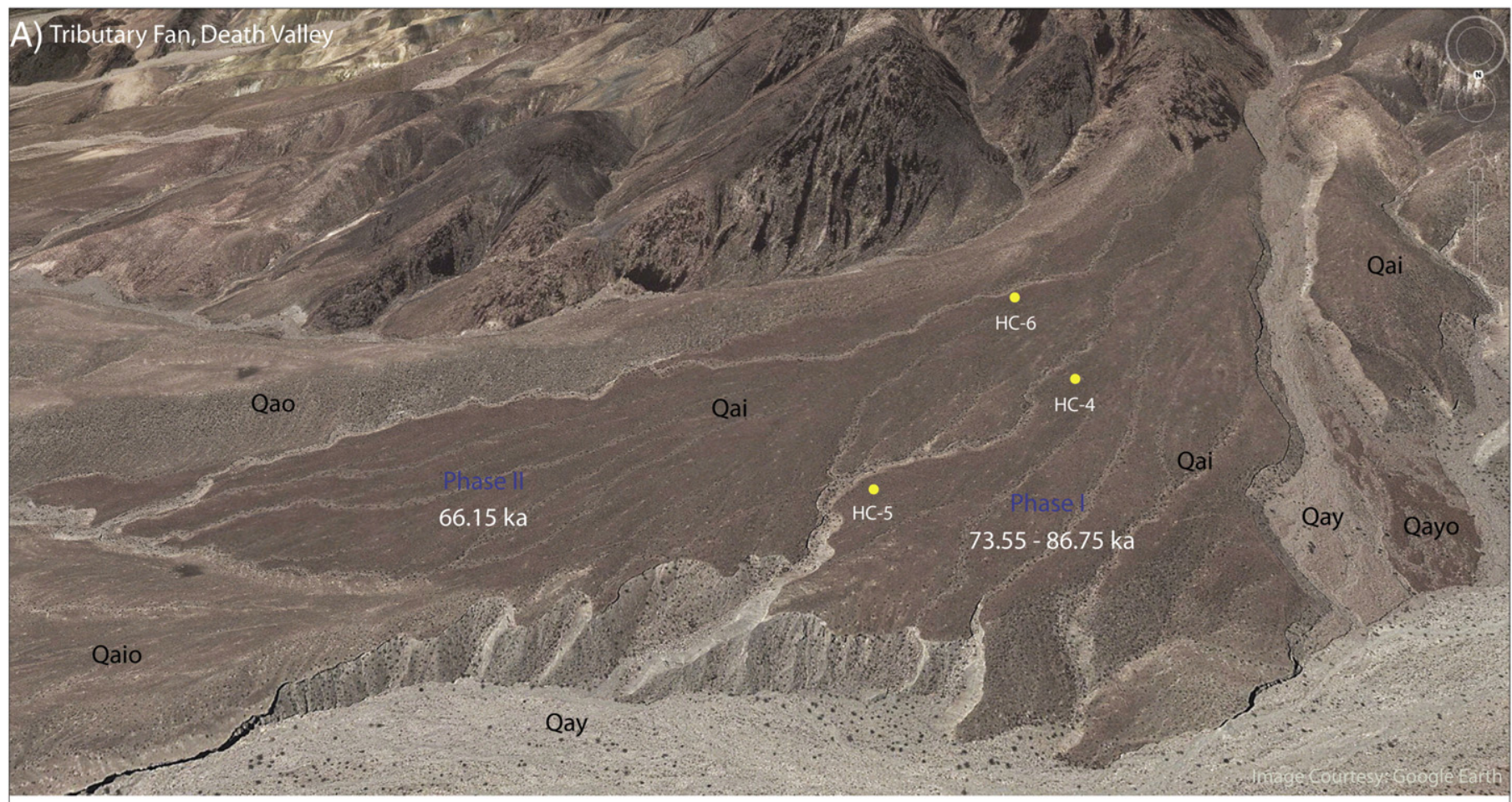

B) $\mathrm{HC}-4$

LU-1/.../LU-5 (WP6e+): 73.55 - 86.75 ka

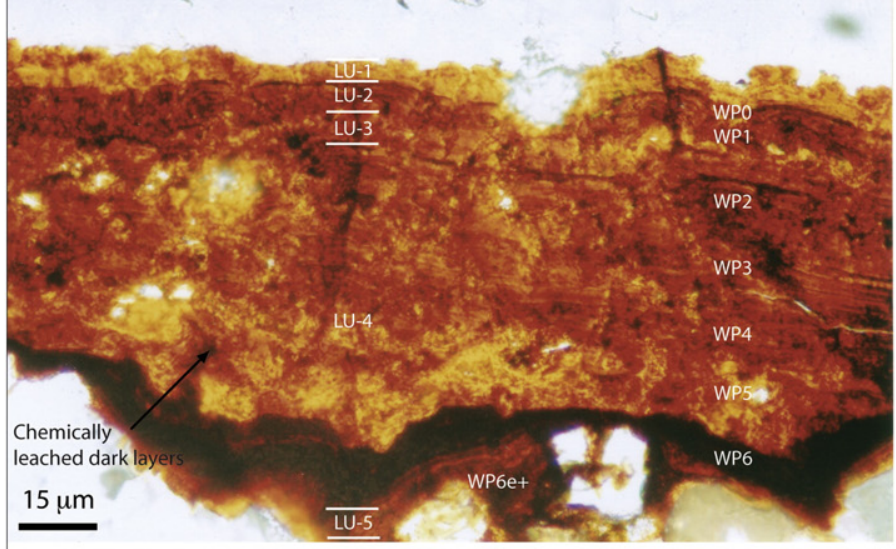

D) HC-6

LU-1/.../LU-4 (WP6c): $66.15 \mathrm{ka}$
C) HC-4 LU-1/.../LU-5 (WP6e+): $73.55-86.75$ ka

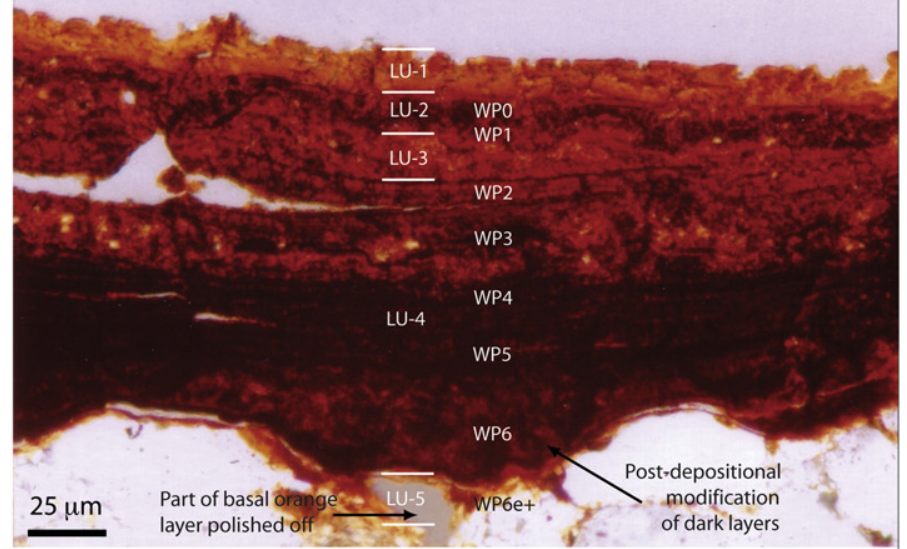

E) HC-6

LU-1/.../LU-4 (WP6c): $66.15 \mathrm{ka}$
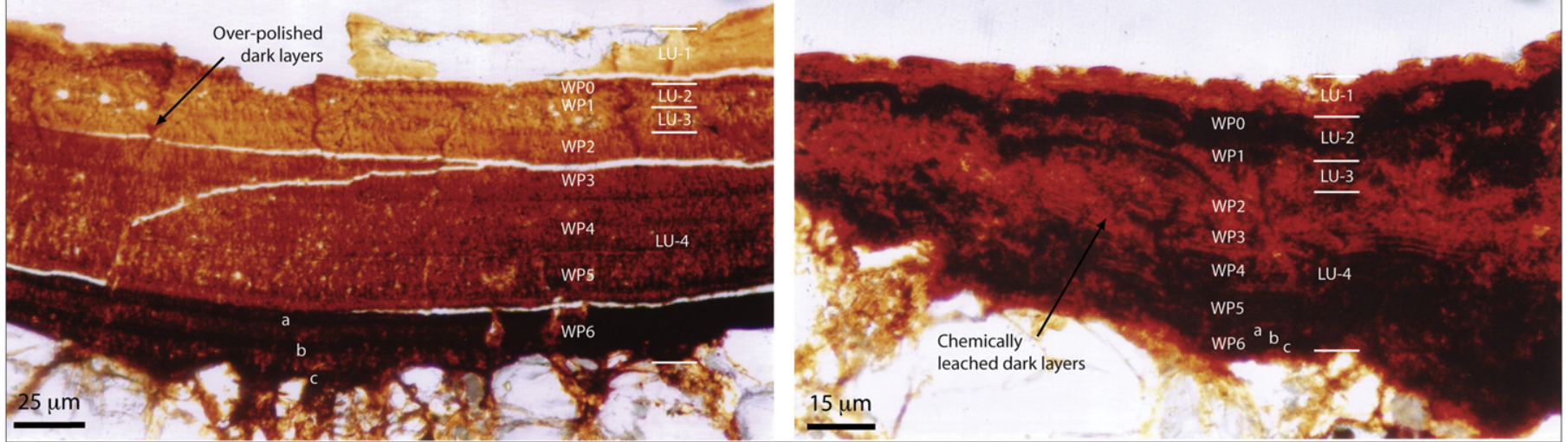


\section{References}

Adams, K.D., Wesnousky, S.G., 1998. Shoreline processes and the age of the Lake Lahontan highstand in the Jessup embayment, Nevada. Geological Society of America Bulletin 110, 1318-1332.

Al Farraj, A., Harvey, A.M., 2004. Late Quaternary interactions between aeolian and fluvial processes: a case study in the northern UAE. Journal of Arid Environments 56, 235-248.

Alley, R., Meese, D., Shuman, C., Gow, A., Taylor, K., Grootes, P., White, J., Ram, M., Waddington, E., Mayewski, P., Zielinski, G., 1993. Abrupt increase in Greenland snow accumulation at the end of the Younger Dryas event. Nature 362, 527-529. http://dx.doi.org/10.1038/362527a0.

Anderson, R.F., Ali, S., Bradtmiller, L.I., Nielsen, S.H.H., Fleisher, M.Q., Anderson, B.E., Burckle, L.H., 2009. Wind-driven upwelling in the Southern Ocean and the deglacial rise in atmospheric $\mathrm{CO}_{2}$. Science 323, 1443-1448.

Armstrong, P.A., Perez, R., Owen, L.A., Rinkel, R.C., 2010. Timing and controls on late Quaternary landscape development along the eastern Sierra Mayor range front in northern Baja California, Mexico. Geomorphology 114, 415-430.

Asmerom, Y., Polyak, V.J., Burns, S.J., 2010. Variable winter moisture in the southwestern United States linked to rapid glacial climate shifts. Nature Geoscience 3, 114-117. http://dx.doi.org/10.1038/NGEO754.

Bacon, S.N., McDonald, E.V., Caldwell, T.G., Dalldorf, G.K., 2010. Timing and distribution of alluvial fan sedimentation in response to strengthening of late Holocene ENSO variability in the Sonoran Desert, southwestern Arizona, USA. Quaternary Research 73, 425-438. http://dx.doi.org/10.1016/j.yqres.2010.01.004.

Baied, C.A., Somonte, C., in press. Mid-Holocene geochronology, palaeoenvironments, and occupational dynamics at Quebrada De Amaicha, Tucuman, Argentina. Quaternary International. http://dx.doi.org/10.1016/j.quaint.2012.11.025.

Ballantyne, C.K., Stone, J.O., 2004. The Beinn Alligin rock avalanche, NW Scotland: cosmogenic Be-10 dating, interpretation and significance. The Holocene 14, 448-453.

Barringer, D.M., 1905. Coon Mountain and its crater. Proceedings of the Academy of Natural Sciences of Philadelphia 57, 861-886.

Barringer, D.M., 1910. Meteor Crater (formerly called Coon Mountain or Coon Butte) in northern central Arizona. Paper presented at the National Academy of Sciences, Princeton University, Nov. 16, 1909 (24 pp. (plus 18 plates, and 3 maps)).

Bartlein, P.J., Anderson, K.H., Anderson, P.M., Edwards, M.E., Mock, C.J., Thompson, R.S., Webb, R.S., Webb III, T., Whitlock, C., 1998. Paleoclimate simulations for North America over the past 21,000 years: features of the simulated climate and comparisons with paleoenvironmental data. Quaternary Science Reviews 17, 549-585.

Behl, R.J., Kennett, J.P., 1996. Brief interstadial events in the Santa Barbara basin, NE Pacific, during the past 60 kyr. Nature 379, 243-246.

Behr, W., Rood, D.H., Fletcher, K.E., Guzman, N., Finkel, R., Hanks, T.C., Hudnut, K.W., Kendrick, K.J., Platt, J.P., Sharp, W.D., Weldon, R.J., Yule, J.D., 2010. Uncertainties in slip rate estimates for the Mission Creek strand of the southern San Andreas fault at Biskra Palms Oasis. Geological Society of America Bulletin 122, 1360-1377.

Bell, J.W., Brune, J.N., Liu, T., Zreda, M., Yount, J.C., 1998. Dating precariously balanced rocks in seismically active parts of California and Nevada. Geology 26, 495-498.

Bender, M., Sowers, T., Dickson, M.L., Orchardo, J., Grootes, P., Mayewski, P.A., Meese, D.A., 1994. Climate correlations between Greenland and Antarctica during the past 100,000 years. Nature 372, 663-666.

Benson, V.L., Curry, D.R., Dorn, R.I., Lajoie, K.R., Oviatt, C.G., Robinson, S.W., Smith, G.I., Stine, S., 1990. Chronology of expansion and contraction of four Great Basin lake systems during the past 35,000 years. Palaeogeography, Palaeoclimatology, Palaeoecology 78, 241-286.

Benson, L., Kashgarian, M., Rubin, M., 1995. Carbonate deposition, Pyramid Lake subbasin, Nevada: 2. Lake levels and polar jet stream positions reconstructed from radiocarbon ages and elevations of carbonates (tufas) deposited in the Lahontan basin. Palaeogeography, Palaeoclimatology, Palaeoecology 117, 1-30.

Bhandari, S., Maurya, D.M., Chamyal, L.S., 2005. Late Pleistocene alluvial plain sedimentation in lower Narmada Valley, western India: paleoenvironmental implications. Journal of Asian Earth Sciences 24, 433-444.

Bierman, P.R., Gillespie, A.R., Caffee, M.W., 1995. Cosmogenic ages for earthquake recurrence intervals and debris flow fan deposition, Owens Valley, California. Science 270, 447-450. http://dx.doi.org/10.1126/science.270.5235.447.

Blackwelder, E., 1932. The age of Meteor Crater. Science 76, 557-560.

Bond, G., Broecker, W., Johnsen, S., McManus, J., Labeyrie, L., Jouzel, J., Bonani, G., 1993. Correlations between climate records from North Atlantic sediments and Greenland ice. Nature 365, 143-147.

Bond, G.C., Showers, W., Cheseby, M., Lotti, R., Almasi, P., deMenocal, P., Priore, P., Cullen, H., Hajdas, I., Bonani, G., 1997. A pervasive millennial-scale cycle in North Atlantic Holocene and glacial climates. Nature 278, 1257-1266.

Bond, G.C., Showers, W., Elliot, M., Evans, M., Lotti, R., Hajdas, I., Bonani, G., Johnson, S., 1999. The North Atlantic's 1-2 kyr climate rhythm, relation to Heinrich events, Dansgaard/Oeschger cycles and the Little Ice Age. In: Clark, P.U., Webb, R.S., Keigwin, L.D. (Eds.), Mechanisms of Global Climate Change at Millennial Time Scales. American Geophysical Union, Washington, DC, pp. 35-58.

Brauer, A., Haug, G.H., Dulski, P., Sigman, D.M., Negendank, J.F.W., 2008. An abrupt wind shift in western Europe at the onset of the Younger Dryas cold period. Nature Geoscience 1, 520-523.

Brierley, G.J., Liu, K., Crook, K.A.W., 1993. Sedimentology of coarse-grained alluvial fans in the Markham Valley, Papua New Guinea. Sedimentary Geology 86, 297-324.

Broecker, W.S., Denton, G.H., 1989. The role of ocean-atmosphere reorganizations in glacial cycles. Geochimica et Cosmochimica Acta 53, 2465-2561.

Broecker, W.S., Liu, T., 2001. Rock varnish: recorder of desert wetness? GSA Today 11 (8), 4-10.
Bull, W.B., 1964. Geomorphology of Segmented Alluvial Fans in Western Fresno County, California. U.S. Geological Survey Professional Paper 352-E, Reston, VA.

Bull, W.B., 1977. The alluvial-fan environment. Progress in Physical Geography 1, $222-270$.

Bull, W.B., 1991. Geomorphic Responses to Climatic Change. Oxford University Press, Oxford, UK.

Bull, W.B., Schick, A.P., 1979. Impact of climatic change on an arid watershed: Nahal Yael, southern Israel. Quaternary Research 11, 153-171. http://dx.doi.org/10.1016/00335894(79)90001-2.

Carignano, C.A., 1999. Late Pleistocene to recent climate change in Cordoba Province, Argentina: geomorphological evidence. Quaternary International 57 (58), 117-134.

Cerveny, N.V., Kaldenberg, R., Reed, J., Whitley, D.S., Simon, J., Dorn, R.I., 2006. A new strategy for analyzing the chronometry of constructed rock features in deserts. Geoarchaeology 21, 282-303.

Chamyal, L.S., Maurya, D.M., Raj, R., 2003. Fluvial systems of the drylands of western India: a synthesis of late Quaternary environmental and tectonic changes. Quaternary International 104, 69-86.

Clark, P.U., Bartlein, P.J., 1995. Correlation of late Pleistocene glaciation in the western United States with North Atlantic Heinrich events. Geology 23, 483-486.

Colman, S.M., Pierce, K.L., Birkeland, P.W., 1987. Suggested terminology for Quaternary dating methods. Quaternary Research 28, 314-319.

Dansgaard, W., Johnsen, S.J., Clausen, H.B., Dahl-Jensen, D., Gundestrup, N.S., Hammer C.U., Hvidberg, C.S., Steffensen, J.P., Sveinbjornsdottir, A.E., Jouzel, J., Bond, G., 1993 Evidence for general instability of past climate from a 250-kyr ice-core record. Nature 364, 218-220.

DeLong, S.B., Pelletier, J.D., Arnold, L.J., 2008. Climate change triggered sedimentation and progressive tectonic uplift in a coupled piedmont-axial system: Cuyama Valley, California, USA. Earth Surface Processes and Landforms 33, 1033-1046.

Denny, C.S., 1965. Alluvial Fans in the Death Valley Region of California and Nevada. U.S. Geological Survey Professional Paper 466, Reston, VA.

Denny, C.S., 1967. Fans and pediments. American Journal of Science 265, 81-105.

Diaz, T.A., Bailley, T.L., Orndorff, R.L., 2002. SEM analysis of vertical and lateral variations in desert varnish chemistry from the Lahontan Mountains, NV. Rocky Mountain Section Meeting, GSA Abstracts with Programs, p. 58.

Dietzel, M., Kolmer, H., Polt, P., Simic, S., 2008. Desert varnish and petroglyphs on sandstone - geochemical composition and climate changes from Pleistocene to Holocene (Libya). Chemie der Erde - Geochemistry 68 (1), 31-43. http:// dx.doi.org/10.1016/j.chemer.2007.03.001.

Dorn, R.I., 1988. A rock varnish interpretation of alluvial-fan development in Death Valley, California. National Geographic Research 4, 56-73.

Dorn, R.I., 2009a. The role of climatic change in alluvial fan development, In: Abrahams, A.D., Parsons, A.J. (Eds.), Geomorphology of Desert Environments, 2nd edition. Springer, New York, NY, pp. 723-742.

Dorn, R.I., 2009b. Rock varnish and its use to study climatic change in geomorphic settings, In: Abrahams, A.D., Parsons, A.J. (Eds.), Geomorphology of Desert Environments, 2nd edition. Springer, New York, NY, pp. 657-673.

Dorn, R.I., 2010. Debris flows from small catchments of the Ma Ha Tuak Range, metropolitan Phoenix, Arizona. Geomorphology 120, 339-352. http://dx.doi.org/ 10.1016/j.geomorph.2010.04.008.

Dorn, R.I., Oberlander, T.M., 1981. Rock varnish origin, characteristics and usage Zeitschrift für Geomorphologie 25, 420-436.

Dorn, R.I., Oberlander, T.M., 1982. Rock varnish. Progress in Physical Geography 6, 317-367.

Enzel, Y., Cayan, D.R., Anderson, R.Y., Wells, S.G., 1989. Atmospheric circulation during Holocene lake stands in the Mojave Desert: evidence of regional climate change. Nature 341, 44-47.

Enzel, Y., Amit, R., Grodek, T., Ayalon, A., Lekach, J., Porat, N., Bierman, P., Blum, J.D., Erel, Y., 2012. Late Quaternary weathering, erosion, and deposition in Nahal Yael, Israel: an "impact of climatic change on an arid watershed"? Geological Society of America Bulletin 124, 705-722. http://dx.doi.org/10.1130/B30538.1.

Eriksson, M.G., Olley, J.M., Payton, R.W., 2000. Soil erosion history in central Tanzania based on OSL dating of colluvial and alluvial hillslope deposits. Geomorphology 36, 107-128.

Evenstar, L., Hartley, A., Rice, C., Stuart, F., Mather, A.E., Guillermo, C., 2006. MiocenePliocene Climate Change in the Peru-Chile Desert. 6th International Symposium on Andean Geodynamics (ISAG 2005, Barcelona), Extended Abstracts, pp. 258-260.

Fairbanks, R.G., Mortlock, R.A., Chiu, T.C., Cao, L., Kaplan, A., Guilderson, T.P., Fairbanks, T.W., Bloom, A.L., Grootes, P.M., Nadeau, M.J., 2005. ${ }^{14} \mathrm{C}$ calibration curve spanning 0 to 50,000 years BP based on paired ${ }^{230} \mathrm{Th} /{ }^{234} \mathrm{U} /{ }^{238} \mathrm{U}$ and ${ }^{14} \mathrm{C}$ dates on pristine corals. Quaternary Science Reviews 24, 1781-1796. http://dx.doi.org/10.1016/ j.quascirev.2005.04.007.

Fletcher, K.E.K., Sharp, W.D., Kendrick, K.J., Behr, W.M., Hudnut, K.W., Hanks, T.C., 2010. ${ }^{230} \mathrm{Th} / \mathrm{U}$ dating of a late Pleistocene alluvial fan along the southern San Andreas fault. Geological Society of America Bulletin 122, 1347-1359.

Foote, A.E., 1891. Geological features of the meteoric locality in Arizona. Proceedings of the Academy of Natural Sciences of Philadelphia 40, 407.

Frankel, K.L., Brantley, K.S., Dolan, J.F., Finkel, R.C., Klinger, R.E., Knott, J.R., Machette M.N., Owen, L.A., Phillips, F.M., Slate, J.L., Wernicke, B.P., 2007. Cosmogenic ${ }^{10} \mathrm{Be}$ and ${ }^{36} \mathrm{Cl}$ geochronology of offset alluvial fans along the northern Death Valley fault zone: implications for transient strain in the eastern California shear zone. Journal of Geophysical Research 112, B06407. http://dx.doi.org/10.1029/ 2006JB004350.

Friend, D.A., Phillips, F.M., Campbell, S.W., Liu, T., Sharma, P., 2000. Evolution of desert colluvial boulder slopes. Geomorphology 36, 19-45. 
Frostick, L.E., Reid, I., 1989. Climatic versus tectonic control of fan sequences - lessons from the Dead Sea, Israel. Journal of the Geological Society of London 146, 527-538.

Gray, S.T., Betancourt, J.L., Fastie, C.L., Jackson, S.T., 2003. Patterns and sources of multidecadal oscillations in drought-sensitive tree-ring records from the central and southern Rocky Mountains. Geophysical Research Letters 30, 1316. http:/ dx.doi.org/10.1029/2002GL016154.

Grootes, P.M., Stuiver, M., White, J.W.C., Johnsen, S., Jouzel, J., 1993. Comparison of oxygen isotope records from the GISP2 and GRIP Greenland ice core. Nature 366, $552-554$

Harvey, A.M., Wigand, P.E., Wells, S.G., 1999. Response of alluvial fan systems to the late Pleistocene to Holocene climatic transition: contrasts between the margins of pluvial Lakes Lahontan and Mojave, Nevada and California, USA. Catena 36, 255-281.

Harvey, A.M., Mather, A.E., Stokes, M., 2005. Alluvial Fans: Geomorphology, Sedimentology, Dynamics - Introduction. A Review of Alluvial-fan Research. Alluvia fans: geomorphology, sedimentology, dynamics: Geological Society Special Publications (London), 251, pp. 1-7.

Hendy, I.L., Kennett, J.P., 1999. Latest Quaternary North Pacific surface-water responses imply atmosphere-driven climate instability. Geology 27, 291-294.

Hetzel, R., Tao, M., Stokes, S., Niedermann, S., Ivy-Ochs, S., Gao, B., Strecker, M.R., Kubik, P.W., 2004. Late Pleistocene/Holocene slip rate of the Zhangye thrust (Qilian Shan, China) and implications for the active growth of the northeastern Tibetan Plateau. Tectonics 23, TC6006.

Hooke, R. LeB, 1972. Geomorphic evidence for late-Wisconsin and Holocene tectonic deformation, Death Valley, California. Geological Society of America Bulletin 83, 2073-2097.

Hooke, R. LeB, Dorn, R.I., 1992. Segmentation of alluvial fans in Death Valley, California: new insights from surface-exposure dating and laboratory modeling. Earth Surface Processes and Landforms 17, 557-574.

Hunt, C.B., Mabey, D.R., 1966. Stratigraphy and Structure, Death Valley, California. U.S Geological Survey Professional Paper 494-A, Reston, VA.

Ibbeken, H., Warnke, D.A., Diepenbroek, M., 1998. Granulometric study of the Hanaupah fan, Death Valley, California. Earth Surface Processes and Landforms 23, 481-492.

Ives, P.C., Levin, B., Robinson, R.D., Rubin, M., 1964. U.S. Geological Survey radiocarbon dates VII. Radiocarbon 6, 37-76.

Jain, M., Tandon, S.J., 2003. Fluvial response to late Quaternary climate changes, western India. Quaternary Science Reviews 22, 2223-2235.

Keefer, D.K., Moseley, M.E., deFrance, S.D., 2003. A 38000-year record of floods and debris flows in the Ilo region of southern Peru and its relation to El Niño events and great earthquakes. Palaeogeography, Palaeoclimatology, Palaeoecology 194 41-77.

Kirby, E., Burbank, D.W., Reheis, M., Phillips, F., 2006. Temporal variations in slip rate of the White Mountain fault zone, eastern California. Earth and Planetary Science Letters 248, 168-185

Klinger, Y., Avouac, J.P., Bourles, D., Tisnerat, N., 2003. Alluvial deposition and lake-leve fluctuations forced by late Quaternary climate change: the Dead Sea case example. Sedimentary Geology 162, 119-139.

Kring, D.A., 2007. Guidebook to the Geology of Barringer Meteorite Crater, Arizona (LPI Contribution Number 1355) Lunar and Planetary Institute, Houston, TX.

Krzyszkowski, D., Zielinkski, T., 2002. The Pleistocene end moraine fans: controls on the sedimentation and location. Sedimentary Geology 149, 73-92.

Lafortune, V., Filion, L., Hétu, B., 2006. Impacts of Holocene climatic variations on alluvial fan activity below snowpatches in subarctic Québec. Geomorphology 76, 375-391.

Lee, M.R., Bland, P.A., 2003. Dating climatic change in hot deserts using desert varnish on meteorite finds. Earth and Planetary Science Letters 206, 187-198.

Liu, T., 1994. Visual microlaminations in rock varnish: a new paleoenvironmental and geomorphic tool in drylands. Ph.D. Thesis, Arizona State University, Tempe, AZ

Liu, T., 2003. Blind testing of rock varnish microstratigraphy as a chronometric indicator: results on late Quaternary lava flows in the Mojave Desert, California. Geomorphology $53,209-234$

Liu, T., Broecker, W.S., 2000. How fast does rock varnish grow? Geology 28, 183-186.

Liu, T., Broecker, W.S., 2007. Holocene rock varnish microstratigraphy and its chronometric application in the drylands of western USA. Geomorphology 84 $1-21$.

Liu, T., Broecker, W.S., 2008a. Rock varnish microlamination dating of late Quaternary geomorphic features in the drylands of western USA. Geomorphology 93, 501-523.

Liu, T., Broecker, W.S., 2008b. Rock varnish evidence for latest Pleistocene millennialscale wet events in the drylands of western United States. Geology 36, 403-406.

Liu, T., Dorn, R.I., 1996. Understanding spatial variability in environmental changes in drylands with rock varnish microlaminations. Annals of the Association of American Geographers 86, 187-212.

Liu, T., Broecker, W.S., Bell, J.W., Mandeville, C.W., 2000. Terminal Pleistocene wet event recorded in rock varnish from Las Vegas Valley, southern Nevada. Palaeogeography, Palaeoclimatology, Palaeoecology 161, 423-433.

Lustig, L.K., 1965. Clastic Sedimentation in Deep Springs Valley, California. U.S. Geological Survey Professional Paper 352-F, Reston, VA.

Machette, M.N., Slate, J.L., Phillips, F.M., 2008. Terrestrial Cosmogenic-nuclide Dating of Alluvial Fans in Death Valley, California. U.S. Geological Survey Professional Paper 1755, Reston, VA

Marrero, S., Phillips, F.M., Caffee, M.W., Smith, S.S., Kring, D.A., 2010. Re-dating the Barringer Meteorite Crater (AZ) impact using the cosmogenic chlorine-36 surface exposure method. 73rd Annual Meeting of the Meteoritical Society, held July 2630, 2010 in New York, New York. Meteoritics and Planetary Science, New York (Supplement, id.5150).
Marston, R.A., 2003. Editorial note. Geomorphology 53, 197.

Matmon, A., Schwartz, D.P., Finkel, R., Clemmens, S., Hanks, T.C., 2005. Dating offset fans along the Mojave section of the San Andreas fault using cosmogenic ${ }^{26} \mathrm{Al}$ and ${ }^{10} \mathrm{Be}$. Geological Society of America Bulletin 117, 795-807.

McDonald, E.V., McFadden, L.D., Wells, S.G., 2003. Regional Response of Alluvial Fans to the Pleistocene-Holocene Climatic Transition, Mojave Desert, California. Geological Society of America Special Paper 368, 189-205.

Meese, D.A., Gow, A.J., Grootes, P., Mayewski, P.A., Ram, M., Stuiver, M., Taylor, K.C., Waddington, E.D., Zielinski, G.A., 1994. The accumulation record from the GISP2 core as an indicator of climate change throughout the Holocene. Science 266, $1680-1682$.

C.O.H.M.A.P. Members, 1988. Climatic changes of the last 18,000 years: observations and model simulations. Science 241, 1043-1052.

Mikolajewicz, U., Crowley, T.J., Schiller, A., Voss, R., 1997. Modelling teleconnections between the North Atlantic and North Pacific during the Younger Dryas. Nature 387, 384-387.

Miller, D.M., Schmidt, K.M., Mahan, S.A., McGeehin, J.P., Owen, L.A., Barron, J.A., Lehmkuhl, F., Löhrer, R., 2010. Holocene landscape response to seasonality of storms in the Mojave Desert. Quaternary International 215, 45-61. http://dx.doi.org/10.1016/ j.quaint.2009.10.001.

Nakamura, H., Sampe, T., Goto, A., Ohfuchi, W., Xie, S.P., 2008. On the importance of mid-latitude oceanic frontal zones for the mean state and dominant variability in the tropospheric circulation. Geophysical Research Letters 35, L15709. http:// dx.doi.org/10.1029/2008GL034010.

Nishiizumi, K., Kohl, C.P., Arnold, J.R., Klein, J.R., Fink, D., Middleton, R., 1991. In situ ${ }^{10} \mathrm{Be} /{ }^{26} \mathrm{Al}$ exposure ages at Meteor Crater, Arizona. Geochimica et Cosmochimica Acta 55, 2699-2703.

Nishiizumi, K., Kohl, C.P., Arnold, J.R., Dorn, R.I., Klein, J., Fink, D., Middleton, R., Lal, D., 1993. Role of in situ cosmogenic nuclides ${ }^{10} \mathrm{Be}$ and ${ }^{26} \mathrm{Al}$ in the study of diverse geomorphic processes. Earth Surface Processes and Landforms 18, 407-425.

Oskin, M., Perg, L., Blumentritt, D., Mukhopadhyay, S., Iriondo, A., 2007. Slip rate of the Calico fault: implications for geologic versus geodetic rate discrepancy in the Eastern California Shear Zone. Journal of Geophysical Research 112, B03402. http:// dx.doi.org/10.1029/2006JB004451.

Owen, L.A., Finkel, R.C., Ma, H., Barnard, P.L., 2006. Late Quaternary landscape evolution in the Kunlun Mountains and Qaidam Basin, Northern Tibet: a framework for examining the links between glaciation, lake level changes, and alluvial fan formation. Quaternary International 154-155, 73-86.

Owen, L.A., Frankel, K.L., Knott, J.R., Reynhout, S., Finkel, R.C., Dolan, J.F., Lee, J., 2011. Beryllium-10 terrestrial cosmogenic nuclide surface exposure dating of Quaternary landforms in Death Valley. Geomorphology 125, 541-557. http://dx.doi.org/ 10.1016/j.geomorph.2010.10.024.

Perry, R.S., Adams, J., 1978. Desert varnish: evidence of cyclic deposition of manganese. Nature 276, 489-491.

Phillips, F.M., 2003. Cosmogenic ${ }^{36} \mathrm{Cl}$ ages of Quaternary basalt flows in the Mojave Desert, California, USA. Geomorphology 53, 199-208.

Phillips, F.M., Zreda, M.G., Smith, S.S., Elmore, D., Kubik, P.W., Dorn, R.I., Roddy, D. 1991. Age and geomorphic history of Meteor Crater, Arizona, from cosmogenic $\mathrm{Cl}-36$ and $\mathrm{C}-14$ in rock varnish. Geochimica et Cosmochimica Acta 55, 2695-2698.

Phillips, F.M., Ayarde, J.P., Harrison, J.B., Elmore, D., 2003. Dating rupture events on alluvial fault scarps using cosmogenic nuclides and scarp morphology. Earth and Planetary Science Letters 215, 203-218.

Polyak, V.J., Rasmussen, J.B.T., Asmerom, Y., 2004. Prolonged wet period in the southwestern U.S. through the Younger Dryas. Geology 32, 5-8.

Pope, R.J.J., Wilkinson, K.N., 2005. Reconciling the roles of climate and tectonics in late Quaternary fan development on the Spartan piedmont, Greece. Geological Society Special Publications (London) 251, 133-152.

Potter, R.M., Rossman, G.R., 1977. Desert varnish: the importance of clay minerals. Science 196, 1446-1448.

Putnam, A.E., Schaefer, J.M., Barrell, D.J.A., Vandergoes, M., Denton, G.H., Kaplan, M.R. Finkel, R.C., Schwartz, R., Goehring, B.M., Kelley, S.E., 2010. In situ cosmogenic ${ }^{10}$ Be production-rate calibration from the Southern Alps, New Zealand. Quaternary Geochronology 5, 392-409. http://dx.doi.org/10.1016/j.quageo.20 09.12.0 01.

Reheis, M.C., Redwine, J., 2008. Lake Manix shorelines and Afton Canyon terraces: implications for incision of Afton Canyon. Geological Society of America Special Paper 439, 227-259. http://dx.doi.org/10.1130/2008.2439(10.

Reheis, M.C., Reynolds, R.L., Goldstein, H., Roberts, H.M., Yount, J.C., Axford, Y., Cummings, L.S., Shearin, N., 2005. Late Quaternary eolian and alluvial response to paleoclimate, canyonlands, southeastern Utah. Geological Society of America Bulletin 117, 1051-1069.

Repka, J.L., Anderson, R.S., Frinkel, R.C., 1997. Cosmogenic dating of fluvial terraces, Fremont River, Utah. Earth and Planetary Science Letters 152, 59-73.

Ritz, J.F., Bourles, D., Brown, E.T., Carretier, S., Chery, J., Enhtuvshin, B., Galsan, P. Finkel, R.C., Hanks, T.C., Kendrick, K.J., Philip, H., Raisbeck, G., Schlupp, A., Schwartz, D.P., Yiou, F., 2003. Late Pleistocene to Holocene slip rates for the Gurvan Bulag thrust fault (Gobi-Altay, Mongolia) estimated with ${ }^{10} \mathrm{Be}$ dates. Journal of Geophysical Research 108 (B3), 2162. http://dx.doi.org/10.1029/ 2001JB000553.

Roberts, N., Barker, P., 1993. Landscape stability and biogeomorphic response to past and future climatic shifts in intertropical Africa. In: Thomas, D.S.G., Allison, R.J. (Eds.), Landscape Sensitivity. John Wiley \& Sons, London, pp. 65-82.

Shoemaker, E.M., 1983. Asteroid and comet bombardment of the Earth. Annual Review of Earth and Planetary Sciences 11, 461-494.

Shoemaker, E.M., 1987. Meteor Crater, Arizona. Geological Society of America Centennial Field Guide - Rocky Mountain Section, pp. 399-404. 
Shoemaker, E.M., Kieffer, S.W., 1974. Guidebook to the Geology of Meteor Crater, Arizona Meteoritical Society, 37th Annual Meeting. Arizona State University Centre for Meteorite Studies, Tempe, AZ.

Sohn, M.F., Mahan, S.A., Knott, J.R., Bowman, D.D., 2007. Luminescence ages for alluvial-fan deposits in southern Death Valley. Implications for climate-driven sedimentation along a tectonically active mountain front. Quaternary International 166, 49-60.

Stirling, M., Ledgerwood, J., Liu, T., Apted, M., 2010. Age of unstable bedrock landforms southwest of Yucca Mountain, Nevada, and implications for past ground motions. Bulletin of the Seismological Society of America 100, 74-86. http://dx.doi.org/ 10.1785/0120080359.

Sutton, S.R., 1985. Thermoluminescence measurements on shock-metamorphosed sandstone and dolomite from Meteor Crater, Arizona. 2. Thermoluminescence age of Meteor crater. Journal of Geophysical Research 90, 3,690-3,700.

Throckmorton, C.K., Reheis, M.C., 1993. Late Pleistocene and Holocene Environmental Changes in Fish Lake Valley. Nevada-California: Geomorphic Response of Alluvial Fans to Climate Change. U.S. Geological Survey Open File Report, Reston, VA, pp. 93-620.

Tilghman, B.C., 1905. Coon Butte, Arizona. Proceedings of the Academy of Natural Sciences of Philadelphia 57, 887-914.

Toggweiler, J.R., 2009. Shifting westerlies. Science 323, 1434-1435.

van der Woerd, J., Tapponnier, P., Ryerson, F.J., Mériaux, A.S., Meyer, B., Gaudemer, Y., Finkel, R.C., Caffee, M.W., Zhao, G., Xu, Z., 2002. Uniform postglacial slip-rate along the central $600 \mathrm{~km}$ of the Kunlun Fault (Tibet), from ${ }^{26} \mathrm{Al},{ }^{10} \mathrm{Be}$ and ${ }^{14} \mathrm{C}$ dating of riser offsets, and climatic origin of the regional morphology. Geophysical Journal International 148, 356-388. http://dx.doi.org/10.1046/j.1365-246X.2002.01556.X.

van der Woerd, J., Klinger, Y., Sieh, K., Tapponnier, P., Ryerson, F.J., Meriaux, A., 2006. Long-term slip rate of the southern San Andreas fault from ${ }^{10} \mathrm{Be}-{ }^{26} \mathrm{Al}$ surface exposure dating of an offset alluvial fan. Journal of Geophysical Research 111, B04407. http://dx.doi.org/10.1029/2004JB003559.

Vassallo, R., Ritz, J.F., Braucher, R., Carretier, S., 2005. Dating faulted alluvial fans with cosmogenic ${ }^{10} \mathrm{Be}$ in the Gurva Bogd mountain range (Gobi-Altay, Mongolia): climatic and tectonic implications. Terra Nova 17, 278-285. http://dx.doi.org/10.1111/j.13653121.2005.00612.x.

Wells, S.G., McFadden, L.D., Dohrenwend, J.C., 1987. Influence of late Quaternary climatic changes on geomorphic and pedogenic processes on a desert piedmont, eastern Mojave Desert, California. Quaternary Research 27, 130-146.

Zehfuss, P.H. Bierman, P.R. Gillespie, A.R., Burke, R.M. Caffee, M.W. 2001. Slip rates on the Fish Spring fault, Owens Valley, California, deduced from cosmogenic ${ }^{10} \mathrm{Be}$ and ${ }^{26} \mathrm{Al}$ and soil development on fan surfaces. Geological Society of America Bulletin 113 241-255. http://dx.doi.org/10.1130/0016-7606(2001) 113<0241:SROTFS>2.0.CO;2.

Zerboni, A., 2008. Holocene rock varnish on the Messak plateau (Libyan Sahara): chronology of weathering processes. Geomorphology 102, 640-651. 